\title{
Silicon heterojunction solar cells: Recent technological development and practical aspects - from lab to industry
}

\author{
Jan Haschke*, Olivier Dupré, Mathieu Boccard, Christophe Ballif \\ Ecole Polytechnique Fédérale de Lausanne, Institute of Microengineering (IMT), Photovoltaics and Thin-Film Electronics Laboratory (PV-lab), Rue de la Maladière 71B, \\ CH-2002 Neuchâtel, Switzerland
}

\section{A R T I C L E I N F O}

\section{Keywords:}

Silicon heterojunction review

Implied fill-factor

Simulation

\begin{abstract}
A B S T R A C T
We review the recent progress of silicon heterojunction (SHJ) solar cells. Recently, a new efficiency world record for silicon solar cells of $26.7 \%$ has been set by Kaneka Corp. using this technology. This was mainly achieved by remarkably increasing the fill-factor $(F F)$ to $84.9 \%$ - the highest $F F$ published for a silicon solar cell to date. High FF have for long been a challenge for SHJ technology. We emphasize with the help of simulations the importance of minimised recombination, not only to reach high open-circuit voltages, but also high $F F$, and discuss the most important loss mechanisms. We review the different cell-to-module loss and gain mechanisms putting focus on those that impact FF. With respect to industrialization of SHJ technology, we discuss the current hindrances and possible solutions, of which many are already present in industry. With the intrinsic bifacial nature of SHJ technology as well as its low temperature coefficient record high energy production per rated power is achievable in many climate regions.
\end{abstract}

\section{Introduction}

In recent years, an increasing number of silicon solar cells were reported that feature energy conversion efficiencies greater than $25 \%$ [1-6]. One key element that these solar cells all have in common is that passivating contacts are used for charge carrier collection. Such contacts enable high efficiencies through the reduction of recombination by the displacement of the metal contact from the silicon surface. One possible approach is the use of silicon heterojunction (SHJ) contacts formed by the deposition of hydrogenated amorphous silicon ( $a-\mathrm{Si}: \mathrm{H})$ layers on the surfaces of the silicon absorber. Combining intrinsic $a$ $\mathrm{Si}: \mathrm{H}$ layers ( $a$-Si:H(i)) that provide excellent defect passivation at the silicon surface in stacks with p- or n-doped $a$-Si: $\mathrm{H}$, enables the formation of selective and passivating contacts. The achievement of fillfactors (FF) well above $80 \%$ has been for long a challenge for SHJ solar cells in both academia and industry, while this was not the case for homojunction solar cells. Kinoshita et al. of the company Sanyo Corp. (now Panasonic Corp.) were the first to publish a FF above $80 \%$ in 2011 [7]. As can be seen from Fig. 1, at that time this was still $2 \%$ abs below the $F F$ of the long-lasting world record obtained on a laboratory Passivated Emitter and Rear Contact ${ }^{1}$ (PERC) solar cell ( $F F=82.9 \%$ [8]). It took until 2013 that Taguchi et al. from Panasonic Corp. published a SHJ solar cell with a $F F$ of $83.2 \%$ [9], exceeding the $F F$ of the laboratory PERC cell. The efficiency of the cell reported by Taguchi et al., however, was still below $25 \%$ as a result of a relatively low shortcircuit current $\left(J_{\mathrm{SC}}\right)$. The most common approach to attain the highest possible $J_{\mathrm{SC}}$ of solar cells is to place both carrier collecting contacts at the rear side of the solar cell, avoiding both shadowing by the metal contact grid as well as parasitic absorption in the front contact layers. The latter is specifically limiting two-side contacted SHJ solar cells, due to the high absorption coefficient of $a-\mathrm{Si}: \mathrm{H}$ in the visible spectrum. We discuss this issue ( $J_{\mathrm{SC}}$ for two-side $\mathrm{SHJ}$ ) in Section 2.3.1.

A challenge for back contacted SHJ solar cells is that only half of the wafer surface is available for contact formation. In combination with the general challenge to obtain low-ohmic contacts with SHJ this explains the reduction in FF of the IBC-SHJ solar cell presented by Masuko et al. [2] compared with the previous SHJ record [9]. Still, the application of an all-back-contact architecture led to an increase in $J_{\mathrm{SC}}$ and with an efficiency of $25.6 \%$ set a new record for c-Si solar cells in 2014 [2].

In March 2017, Kaneka Corp. published their work on IBC-SHJ with the first silicon solar cell exceeding $26 \%$ efficiency [10] with a FF of $83.8 \%$. This high FF was enabled by a series resistance of only $0.32 \Omega \mathrm{cm}^{2}$, demonstrating that very low-resistive contacts can be achieved also with SHJ contacts. Later in 2017, further progress in efficiency was reported, culminating at $26.7 \%$ [4]. This cell featured an

\footnotetext{
* Corresponding author.

E-mail address: jan.haschke@epfl.ch (J. Haschke).

${ }^{1}$ Also referred to as Passivated Emitter and Rear Cell.
} 


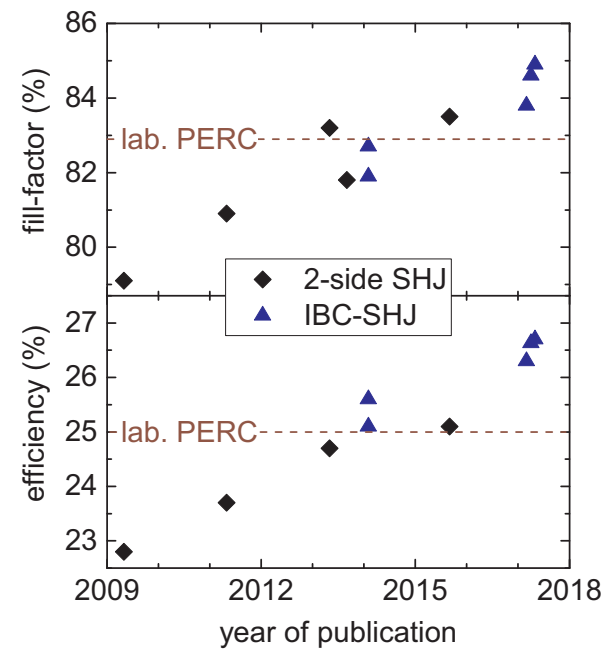

Fig. 1. Recent progress of efficiency and fill-factor for SHJ solar cells. For comparison, the long-lasting record of $c$-Si solar cells, a laboratory PERC cell [8], is included as dashed line.

even higher $F F$ of $84.9 \%$, enabled by its very low series resistance of only $0.2 \Omega \mathrm{cm}^{2}$ [1]. To reach such high $F F$, not only transport losses have to be minimal but also recombination in low injection conditions, both in the silicon absorber as well as at its surfaces, needs to be sufficiently low [11]. These aspects were not covered in previous review articles $[12,13]$. The impact of recombination in the silicon absorber on the FF was covered by Leilaeioun \& Holman, but the surface recombination was not considered in this paper [14].

Therefore, in this review, we put focus on recent progress of the FF in SHJ solar cells. After introducing possible SHJ device architectures in Section 2.1, we discuss the prerequisites to reach high $F F$ with the help of the simulation of implied $J V$ characteristics considering recombination both in the absorber and at its surfaces in Section 2.2.2. In Section 2.3 we review the loss mechanisms affecting the $J_{\mathrm{SC}}, V_{\mathrm{OC}}$, and $F F$ of SHJ devices, including resistive losses into our calculations (Section 2.3.3). The impact of different interconnection technologies as well as binning of cells with slightly different JV characteristics on the FF of a module is discussed in Section 3, while possible challenges for mass production are covered in Section 4.

\section{SHJ solar cell devices}

Silicon heterojunction solar cells consist of a crystalline silicon wafer that is passivated on both sides with stacks of intrinsic and doped hydrogenated amorphous silicon ( $a$-Si:H) layers. As the conductivity of intrinsic $a$-Si:H is very low, its thickness should be as low as possible, but a minimum thickness has to be retained to provide sufficient surface passivation (cf. Section 2.2.1). If at the front side, ${ }^{2}$ also the thickness of the doped $a$-Si:H layer should be as low as possible to reduce parasitic absorption (cf. Section 2.3.1). To fully exploit the potential, highquality silicon wafers featuring long charge carrier lifetimes have to be used. High efficiencies can be obtained on both doping types [15]. Nonetheless, most SHJ solar cells reported are based on n-type wafers due to its lower sensitivity towards impurities and the resulting superior charge carrier lifetimes [12].

With the very low surface recombination rates enabled by $a$-Si:H passivation, minority-charge-carrier lifetimes in the range of several milliseconds are obtained which enable open-circuit voltages well above $700 \mathrm{mV}$. At the front side, a metal grid is placed for charge carrier transport. Below the grid, usually a transparent conductive oxide (TCO)

\footnotetext{
${ }^{2}$ The front side is the side facing the sun.
}

is needed to provide lateral conductivity. Other than with diffused junctions, the doped $a$-Si:H layers are laterally not conductive enough to fulfill this task. At the front side, the TCO serves also as an antirefection coating (ARC). For stand-alone SHJ solar cells, its thickness is fixed to around $75 \mathrm{~nm}$ for optimal AR effect. When under glass, as in a module, this shifts to lower thickness.

\subsection{Possible device architectures}

To realize silicon heterojunction solar cells, different device architectures are possible of which the three most common are depicted in Fig. 2. All have in common that they are intrinsically bifacial, which can lead to $25-30 \%$ higher energy yield ${ }^{3}[16,17]$. In the front junction configuration (Fig. 2a), the minority charge carrier collecting contact is situated at the front side of the solar cell absorber. Here, the minoritycharge-carriers are generated close to their collecting contact, which enables higher short circuit current density for short-lifetime absorber material. While this is explaining why the front junction configuration is currently the most widely-used one in industry (Al-BSF are such cells), it is of less importance for SHJ solar cells. As long as minority charge carriers can reach their collecting contact, high current densities can be obtained regardless of the position of the minority-charge-carrier contact. High charge-carrier lifetimes in the absorber and excellent surface passivation are a prerequisite to obtain this condition. Both are obtained in SHJ solar cells due to the excellent surface passivation of $a$ $\mathrm{Si}: \mathrm{H}$ and the high-quality wafers used as absorber material.

Therefore, SHJ solar cells enable other device architectures, including with a minority-carrier-collecting contact on the rear side (Fig. 2c). Regarding SHJ solar cells, the rear junction ${ }^{4}$ configuration enables the use of less conductive, and therefore more transparent TCOs at the front side as lateral current transport can also take place in the wafer [19]. Furthermore, the contact formation for holes in SHJ is often considered to be more delicate compared with the electron contact [20]. Thus, placing the p-contact on the rear side enables the use of different materials i.e. thicker or more highly doped at the cost of transparency which would be a drawback in standard configuration. Despite this theoretical advantage, we would like to point out that the highest reported efficiency of a twoside contacted SHJ (which is the highest-efficiency two-side contacted large-area silicon solar cell) was obtained on an n-type wafer with the $a$ Si:H hole-contact at the front $[11,21]$.

However, for both aforementioned configuration, even assuming that fully transparent materials could be engineered to form the front contact, still a front metal grid is needed, which will lead to current losses due to shadowing. In order to tap the full efficiency potential, both contacts have to be placed at the rear side of the solar cell. This, in addition, further broadens the spectrum of possible contact materials used as neither thickness nor transparency are limiting the choice. The most common approach to realize such a cell architecture is to form the contacts for both polarities in an interdigitated pattern at the rear side of the solar cell, described as interdigitated back contacts (IBC, Fig. 2d). The omission of the thickness restraint for the doped layers results also in an increased robustness towards sputter damage and can be beneficial for contact formation and band alignment [22-25].

The major challenge for the industrial production of IBC devices is the cost-efficient formation of both contacts at the rear side of the wafer. Most IBC-SHJ devices reported so far rely on photolithograpy $[26,5,27]$. The $a$-Si:H layers are either structured by doping-selective etching in alkaline solutions $[5,27]$ or using additional layers as etching barriers $[26,28]$. Laser structuring in combination with sacrificial layers has also been investigated [29-31], the highest reported efficiency is $22.5 \%$ [31].

\footnotetext{
${ }^{3}$ Depending on site characteristics like albedo and row-to-row spacing.

4 Often referred to also as so-called "rear emitter" configuration. As "emitter" is a misnomer regarding PV [18], we use rear junction as identifier.
} 
a)

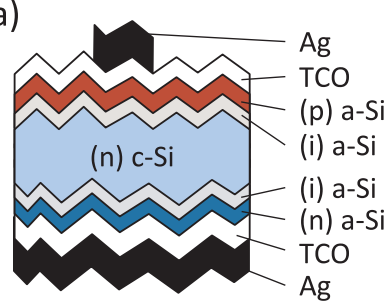

front junction mono-facial

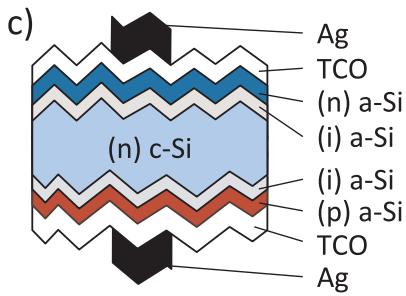

rear junction bi-facial

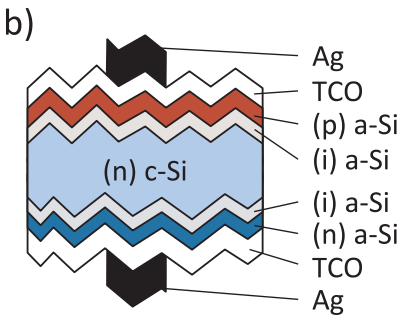

front junction bi-facial

d)

(p) a-Si

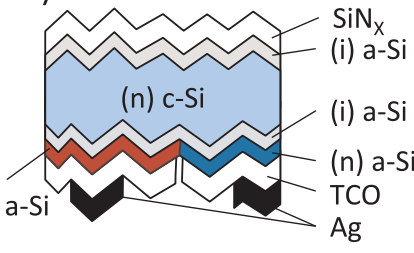

interdigitated back contacts

Fig. 2. Device architectures for SHJ solar cells. a) Front junction mono-facial with minority-carrier-collecting contact on the front side, b) front junction bifacial, c) rear junction bi-facial with minority-carrier-collecting contact on the rear, d) interdigitated back contacts (IBC) with charge carriers of both polarities collected on the rear side.

An approach that drastically reduces processing steps is the combination of in-situ shadow masking and the use of a recombination junction [32-34]. Using such recombination junction, one of the doped layers can be applied on the full area, reducing to two the number of patterning steps (one for one of the contact, one for the electrode) and one single alignment step [34]. In the case of this IBC configuration, only half of the area is available for charge collection, making contact resistance more problematic to reach low series resistance values. Yet, the excellent results recently obtained in several companies $[35,1,5,2]$ using an all-rear-

a)

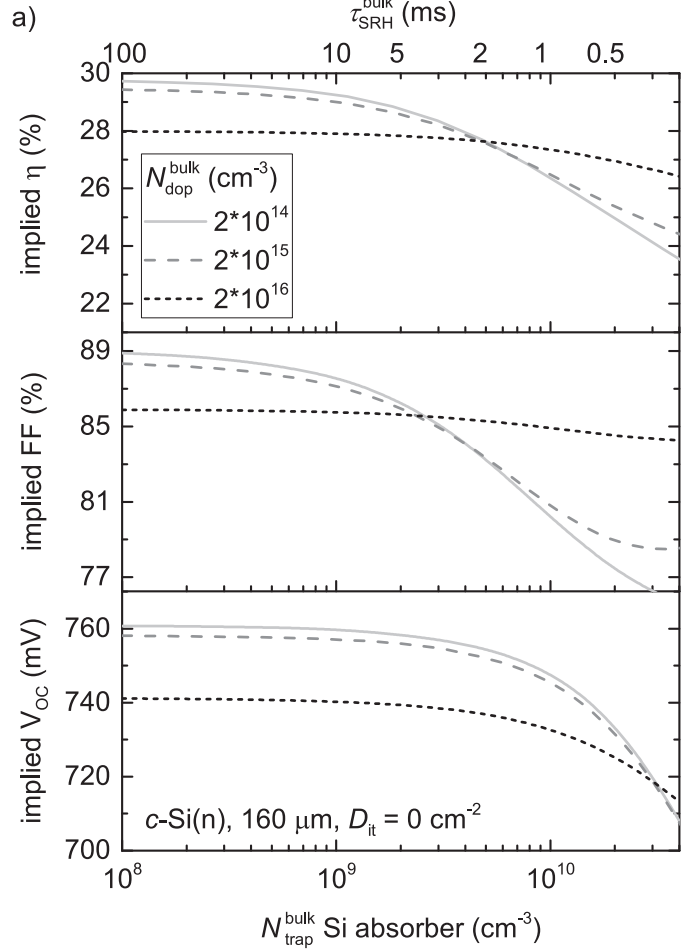

contacted architecture indicate that this can be overcome.

\subsection{Recombination dynamics in silicon solar cells}

\subsubsection{Surface passivation with amorphous Silicon}

The history of electronic-quality amorphous silicon can be traced back to the findings of Chittick et al. from 1968, when they demonstrated that intrinsic, highly resistive material could be grown from plasma-enhanced chemical vapour deposition (PECVD). The demonstration of doping by adding phosphorous and boron in the gas mixture enabled this material to be used in solar cells, initially as absorber and contact [36], later on as contact only for a silicon-wafer-based solar cell in the heterojunction architecture. Excellent passivation relies on atomically sharp interfaces between the crystalline silicon wafer and the amorphous silicon layer. A high hydrogen content has also been shown as necessary for best passivation results $[37,38,12]$. The properties of recombinationactive defects at the surface of an $a$-Si:H-passivated wafer were studied in details in recent years, revealing that they are similar to bulk defects in $a$ Si:H $[39,40]$. This is linked to the fact that, for thin layers, the charges photogenerated in the silicon wafer are sensitive to the defects through the whole bulk of the $a$-Si:H layer, the surface defect density $\left(D_{\text {it }}\right)$ corresponding to the projected defect density of the film [39]. In recent years, the effect of light illumination on the passivation properties of $a$ Si:H layers was studied and its kinetics revealed, with clear indication that the effect of light soaking depends on the passivating structure, passivation from intrinsic layers being prone to light-induced degradation, whereas passivation from stacks of intrinsic and doped layers are prone to light-induced improvement [41-43].

\subsubsection{Influence of charge carrier lifetime on device performance}

The device performance depends strongly on charge carrier lifetime. Knowing the injection dependent recombination of the solar cell device is important, especially for the optimization of solar cells with passivated contacts. The upper limits for fill-factor and open-circuit voltage are set by charge carrier recombination and are referred to as implied

b)

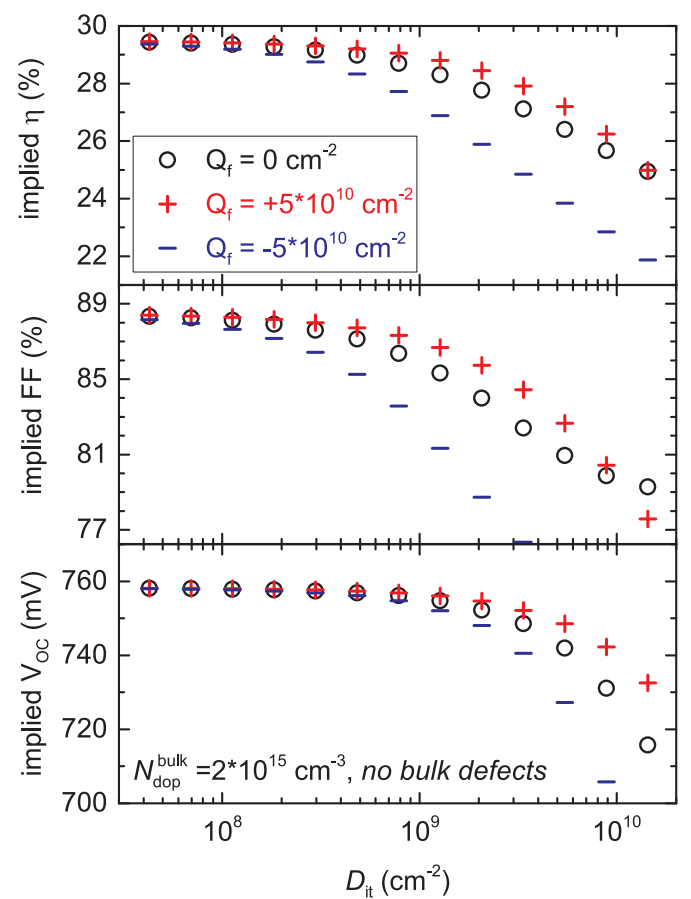

Fig. 3. Efficiency, fill-factor and $V_{\mathrm{OC}}$ of implied $J V$-curves, calculated from charge carrier lifetime. a) For different defect concentrations and doping concentrations in an $n$-type silicon absorber. b) For different interface state densities $D_{\mathrm{it}}$ and surface fixed charge densities $Q_{\mathrm{f}}$, assuming identical conditions for both absorber surfaces. 
values - $i F F$ and $i V_{\mathrm{OC}}$. If there are no further losses, the parameters $F F$ and $V_{\mathrm{OC}}$ are equal to $i F F$ and $i V_{\mathrm{OC}}$. Ideally, recombination through defect states in the absorber and at its surfaces is so low that $i V_{\mathrm{OC}}$ and $i F F$ are limited by intrinsic recombination i.e. Auger and radiative recombination. In Fig. 3, we show the impact of recombination in the absorber (Fig. 3a) and at its surfaces (Fig. 3b) on the implied values of $V_{\mathrm{OC}}, F F$, and efficiency, as obtained from the simulation of injection dependent charge carrier lifetime. Details on the simulation can be found in A.2.

Regarding open-circuit voltage, the trap density in the bulk $N_{\text {trap }}^{\text {bulk }}$ needs to be sufficiently low to allow for charge carrier lifetimes $\tau_{\mathrm{SRH}}^{\text {bulk }}$ of at least $2 \mathrm{~ms}$ in order that $V_{\mathrm{OC}}$ is close to the intrinsic limit. This limit depends on the doping density in the absorber and decreases with increasing doping density. For lower lifetime absorber material $\left(\tau_{\mathrm{SRH}}^{\text {bulk }}\right.$ $<500 \mu \mathrm{s}$ ), a higher doping density allows for higher $V_{\mathrm{OC}}$ as can be seen in Fig. 3. This is explained by the position of the quasi-fermi level of the majority charge carriers, which is shifted closer to the band-edge, allowing for higher $V_{\mathrm{OC}}$. This can be also beneficial for thinner absorbers, when long diffusion lengths are not mandatory [44].

Also recombination at the surfaces can limit the $V_{\mathrm{OC}}$ and is characterised by an interface state density ${ }^{5} D_{\mathrm{it}}$ and a fixed charge $Q_{\mathrm{f}}$. For the simulations in this paper we chose identical $D_{\text {it }}$ and $Q_{\mathrm{f}}$ for both surfaces. For typical values of $Q_{\mathrm{f}}$ as chosen for the example shown in Fig. 3, $i V_{\mathrm{OC}}$ follows a similar trend versus $D_{\mathrm{it}}$ as for a variation of $N_{\text {trap }}^{\text {bulk }}$.

The implied fill-factor $i F F$ deviates earlier (for lower defect densities) from its intrinsic limit compared with the $i V_{\mathrm{OC}}$. This can be seen from Fig. 3, for both recombination in the absorber as well as at its surfaces. The prerequisites to reach a high $i F F$ are therefore more demanding. While for $i V_{\mathrm{OC}}$, a $\tau_{\mathrm{SRH}}^{\text {bulk }}$ of $>2 \mathrm{~ms}$ is sufficient to be limited by intrinsic recombination, for $i F F, \tau_{\mathrm{SRH}}^{\text {bulk }}$ needs to be $>5 \mathrm{~ms}$. Similarly, $D_{\mathrm{it}}$ needs to be kept at a minimum to ensure high $i F F$. Low defect recombination is thus primarily important to obtain a high $i F F$, as e.g. also pointed out by Adachi et al. [11].

\subsection{Loss mechanisms and mitigation strategies}

\subsubsection{Short-circuit current density}

Two-side contacted SHJ solar cells suffer intrinsically from shortcircuit current losses due to reflection at the front-contact grid. These losses are eventually defined by the metalization technique used, as the ideal geometry of the grid depends on the minimum possible finger width and the resistivity of the lines. Using e.g. fine line double stencil printing, finger widths down to $36 \mu \mathrm{m}[46,47]$ are possible, while even narrower lines down to $15 \mu \mathrm{m}$ can be achieved using plating techniques $[48,11]$. Additionally, the sheet resistance of the TCO affects the ideal geometry as a lower sheet resistance allows for wider finger spacing. Yet, if the lower sheet resistance is achieved by increasing the carrier density, this induces higher parasitic absorption from free carriers, referred to as free-carrier absorption (FCA), specially for photons with wavelengths beyond $800 \mathrm{~nm}$. At the front side, this can be mitigated using high mobility TCOs such as IO:H $[49,50]$ or ICO:H $[51,52]$ that provide a sufficiently low sheet resistance despite a low free carrier density.

Besides reflection, parasitic absorption is an important current loss mechanism for two-side SHJ solar cells. At the front-side, photons are absorbed in the $a$-Si:H and TCO layers. Holman et al. state a $J_{\mathrm{SC}}$ loss of $2 \mathrm{~mA} / \mathrm{cm}^{2}$ in the wavelength range between $300 \mathrm{~nm}$ and $800 \mathrm{~nm}$ due to parasitic absorption at the front-side for a typical SHJ solar cell [53] with ITO as TCO. While charge carriers generated in the doped $a$-Si:H can be considered as fully lost due to the short diffusion length in the

\footnotetext{
${ }^{5}$ For our simulations, the term surface state density would be more concise. However, as in SHJ devices the absorber's surfaces are interfaces to the $a$-Si:H layers, we chose the term $D_{\text {it }}$. Note, that the absolute values of $D_{\text {it }}$ depend also on the chosen capture cross sections - we use here the values of ref. [45], summarized in Table A1 in the appendix.
}

material, it is reported that at least parts of the carriers generated in the $a$-Si:H(i) layer are injected in the $c$-Si absorber and thus contribute to $J_{\mathrm{SC}}[53,54]$ Holman et al. estimate that $30 \%$ of the carriers contribute to $J_{\mathrm{SC}}$ [53], while Paduthol et al. report even 40\% [54].

The general guideline to avoid parasitic absorption losses at the front is to reduce the optical thickness $k \cdot t$, i.e. either reduce the thickness $t$ or the extinction coefficient $k$ of the front contact layer. A reduction of $k$ can be achieved by alloying $a$-Si:H with other elements such as carbon $[55,56]$ or oxygen $[57,58]$, to increase the band gap. Unfortunately, in the case of $a-\mathrm{SiO}_{\mathrm{x}}(\mathrm{n})$, the doping efficiency is reduced with increasing oxygen content [59] and thus conductivity is decreased. As a result, the $J_{\mathrm{SC}}$ gain is counterbalanced by a loss in $F F$ and no efficiency gain is achieved. More promising might be the application of a two-phase material such as nanocrystalline silicon oxide $\left(n c-\mathrm{SiO}_{\mathrm{x}}: \mathrm{H}\right)$. In such a material, a columnar nanocrystalline silicon phase providing vertical conductivity is embedded in an amorphous silicon oxide matrix providing enhanced transparency $[60,61]$. For $n c-S i O_{x}: H(n)$ at the front side of a SHJ solar cell, a slightly higher efficiency compared with an oxide-free $n c-S i: H(n)$ reference is reported $[62,63]$. Also the use of nanocrystalline silicon (nc-Si:H) is an option $[20,64]$, due to the lower $k$ of $n c$-Si:H compared with $a$-Si:H in the short wavelength range.

At the rear side, parasitic absorption of photons of IR wavelength can be reduced following the same approach, or with an advanced rear reflector design incorporating a low-refractive index material such as $\mathrm{MgF}_{2}$ as optical spacer to reduce parasitic absorption of the evanescent wave in the back reflector. This approach was proposed by Campbell et al. [65] and further elucidated [66] as well as experimentally shown by Holman et al. [67].

In terms of $J_{\mathrm{SC}}$ the ideal device architecture is the IBC-SHJ. The absence of front contact grid and TCO, as well as the fact that front side layers with excellent passivation and no parasitic absorption can be realized, enables maximum $J_{\mathrm{SC}}$. A possible problem for IBC-SHJ is so called electrical shading $[68,69]$ which occurs when minority charge carriers are generated far from their collecting contact and recombine due to insufficient effective diffusion length at the majority carrier contact or in the silicon absorber.

In Fig. 4 we show the external quantum efficiencies (EQE) of a twoside contacted and an IBC-SHJ solar cell. The most striking difference is the absence of parasitic absorption in the range of 300-600 nm for the IBC-SHJ, the absorber thickness for both cells is $160 \mu \mathrm{m}$. Also shown is the general impact of parasitic absorption in a front $a$-Si:H layer and parasitic absorption in the IR, simulated with increasing parasitic absorption at the rear side of a $160 \mu \mathrm{m}$ thick silicon absorber. Please refer to A.1 for more details.

\subsubsection{Open-circuit voltage}

To reach high open-circuit voltage $\left(V_{\mathrm{OC}}\right)$ in a silicon solar cell, two requirements need to be fulfilled:

(i) defect recombination needs to be low, enabling high excess charge carrier density (that results in high implied $V_{\mathrm{OC}}\left(i V_{\mathrm{OC}}\right)$ ), and

(ii) selectivity at electron- and hole-contacts needs to be sufficiently high in order to achieve charge carrier separation and as a result a potential difference between the contacts (high $V_{\mathrm{OC}}$ ).

The high $V_{\mathrm{OC}}$ is one of the key characteristics of solar cells with passivating contacts. For commonly used high quality silicon absorbers, the $V_{\mathrm{OC}}$ is usually well above $700 \mathrm{mV}$ and, for a good device, limited by intrinsic recombination (Auger \& radiative).

As generally in SHJ solar cells the $a$-Si:H layers are only several nanometers thin, the preservation of surface passivation after the $a-\mathrm{Si}: \mathrm{H}$ deposition is a challenge. Subsequent processes as e.g. the TCO deposition can decrease the surface passivation. When sputtering is used for TCO deposition, ion bombardment and UV plasma luminescence create defects in the $a$-Si:H [70-72] which reduces the surface passivation. Depending on the process conditions during sputtering [72,73], it can be possible to recover surface passivation with low-temperature $\left(\leq 200^{\circ} \mathrm{C}\right)$ annealing, however, in ref. [71] it was observed that the 


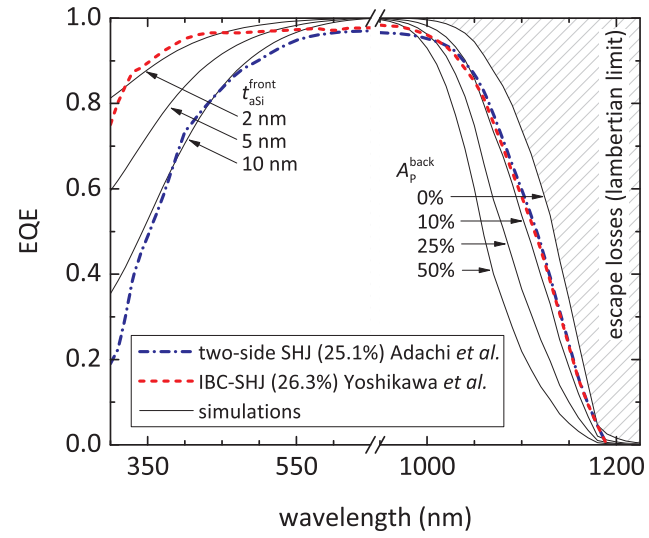

Fig. 4. Experimental external quantum efficiencies (EQE) of a two-side contacted SHJ solar cell [11] and an IBC-SHJ [10]. Also shown are simulated curves assuming no reflection losses, and different levels of parasitic absorption at the front and at the rear, see A.1 for further details. Experimental EQE data with kind permission of Kaneka Corp.

microstructure of the $a$-Si:H is irreversibly altered. Thicker $a$-Si:H can lead to a higher resistance against sputter damage [74] but is unwanted at the front side due to parasitic absorption. A protecting TCO layer applied prior to sputtering with a damage-free technique such as atomic layer deposition (ALD) can fully prevent $V_{\mathrm{OC}}$ loss due to sputter damage when sufficiently thick [75]. Also other deposition techniques such as ion plating can be used to reduce ion bombardment during TCO deposition [51].

Only relevant for academia, where often multiple small $\left(<9 \mathrm{~cm}^{2}\right)$ solar cells are embedded in one wafer, the $V_{\mathrm{OC}}$ of the measured cell can be reduced during the measurement of the $J V$-curve through a mask as in the perimeter region of the cell, no charge carriers are generated and charge carriers generated in the cell area diffuse in the dark perimeter region and recombine [76]. For a typical $4 \mathrm{~cm}^{2} \mathrm{SHJ}$ solar cell, when measured with a shadow mask the $V_{\mathrm{OC}}$ is about $10 \mathrm{mV}$ lower compared with a measurement with full-wafer illumination. ${ }^{6}$ The effect is reduced with increasing area-to-perimeter ratio [77] and becomes negligible for typical SHJ cells with an area $>9 \mathrm{~cm}^{2}$.

Regarding full-wafer solar cells as used in production or industryoriented research, the passivation of the wafer edge becomes increasingly important the higher the $V_{\mathrm{OC}}$ and efficiency of the solar cell. As an example, Kaneka Corp. reports on a SHJ cell on a full wafer $\left(239 \mathrm{~cm}^{2}\right)$ with an efficiency of $24.5 \%$, while to further improve efficiency, they not only report on process improvements but reduced also the cell area to $152 \mathrm{~cm}^{2}$, while still on a 6 in. wafer [11], for a two-side contacted cell. Similarly, an IBC-SHJ solar cell with an efficiency of $26.3 \%$ for a designated area measurement $\left(180 \mathrm{~cm}^{2}\right)$ is measured at $25.6 \%$ when total area is taken into account [78], page 6 .

Besides sufficiently low recombination in the silicon absorber and at its surfaces to obtain a high excess charge carrier density, another requirement is to have contacts with sufficiently high selectivity for the respective polarity. This allows to reach high $V_{\mathrm{OC}}$ values, matching the $i V_{\mathrm{OC}}$. Selectivity is obtained when the contact features a high difference in conductivity for the two polarities [79]. For $a$-Si:H-based contacts, insufficient doping and/or mismatched TCO work function $[23,24,80,22,25]$, or a combination thereof impede this conductivity asymmetry, and cause selectivity-hence $V_{\mathrm{OC}}$-losses. A mismatched TCO workfunction will lead to a depletion of the doped layers at the interface between TCO and the doped layer (cf. band diagram in Fig. 5).

\footnotetext{
${ }^{6}$ This is more pronounced if the perimeter region is electrically connected with a low resistance, as is e.g. the case for multiple rear junction cells when their rear metallization is connected via the measurement chuck during the $J V$ measurement.
}

However, the parameter that is most affected in this case is the FF, as discussed in Section 2.3.3.

\subsubsection{Fill-factor}

Losses in $F F$ of a silicon solar cell can be triggered by the same mechanisms as $V_{\mathrm{OC}}$-losses:

(i) recombination, and

(ii) insufficient conductivity $\sigma_{\mathrm{e} / \mathrm{h}}$ of the respective contact's majority carrier.

Regarding the losses due to recombination, the same principles that impact $V_{\mathrm{OC}}$, as e.g. sputter damage also impact the $F F$ by lowering the implied $F F(i F F)$ of the solar cell. As it leads to an increased $D_{\text {it }}$, sputter damage is more detrimental to the $i F F$ than to the $i V_{\mathrm{OC}}$, as shown in Section 2.2.2. Lifetime at implied open circuit is indeed limited by Auger recombination to lower values than at implied maximum power, making $i F F$ more sensitive to surface recombination than $i V_{\mathrm{OC}}$. Regarding (ii), whereas for the $V_{\mathrm{OC}}$ only the ratio $\sigma_{\mathrm{e}} / \sigma_{\mathrm{h}}$ of the conductivity of electrons and holes at their respective contacts is important, ${ }^{7}$ for a high $F F$, the absolute values of $\sigma_{\mathrm{e}}$ (at the electron-contact) and $\sigma_{\mathrm{h}}$ (at the hole-contact) define if charge carrier transport is limited or not.

As can be seen in Fig. 6, certain $F F$ values can be obtained by different combinations of $i F F$ and ohmic transport losses. For example, a $F F$ of $83.3 \%$ can be obtained assuming a wide range of series resistance values between $0 \Omega \mathrm{cm}^{2}$ and $0.9 \Omega \mathrm{cm}^{2}$, depending on charge carrier recombination dynamics and the resulting $i F F$. This is valid for both recombination in the absorber as well as at its surfaces. Yet, obviously, high $F F$ can only be attained with a combination of low recombination and low series resistance.

In experimental SHJ solar cells, transport limitations are often not fully ohmic and can also be dependent of charge carrier injection level and temperature. Their characterization and analysis of SHJ devices can thus be more challenging using classical analysis methods such as the two-diode model. These methods, however, can still be helpful when allowing e.g. for variable ideality factor $n$ or recombination prefactor $J_{0}$.

A strong temperature dependence of transport in SHJ solar cells is caused when thermionic emission is limiting charge carrier transport. For example, when the $a-\mathrm{Si}: \mathrm{H}(\mathrm{p})$ layer at the TCO/a-Si:H(p) interface is partly depleted (cf. Fig. 5), efficient tunneling from $a$-Si:H(p) to the TCO is prevented, and a non-linear transport barrier is formed. ${ }^{8}$ Tunneling has been shown to be needed when modeling the $a$-Si:H/TCO contact $[25,81]$ and is an important transport mechanism in SHJ solar cells. The $a$-Si:H layer depletion can occur due to a mismatched workfunction of the TCO $[23,24,80,81]$ and is enhanced by insufficient thickness [24] and/or doping of the doped $a$-Si:H layer $[25,23,82,83]$.

One way to counteract the formation of such a transport hindrance is the application of nanocrystalline ${ }^{9}$ silicon $(n c-\mathrm{Si}: \mathrm{H})$ layers $[64,20,63]$. In this material, the fermi-level is closer to the valence or conduction band compared with $a$-Si:H due to its increased doping efficiency. This facilitates the contact formation with the TCO, as it reduces the width of the depletion region in the doped layer. It was reported by Nogay et al. that especially the hole contact (TCO/p) benefits from the increased conductivity [20], contact resistivities (for both electron and holecontact) are reduced by a factor of three, and their temperature dependence becomes less pronounced.

\footnotetext{
${ }^{7}$ As there is no current flow in $V_{\mathrm{OC}}$, the absolute value of the conductivity is not important. It is only important, that e.g. at the hole contact the conductivity for electrons is much lower than the one of holes, and vice versa.

${ }^{8}$ Such a barrier is often described also as "diode" or "counter-diode".

${ }^{9}$ In literature, also the term microcrystalline is used for such materials. As grain-sizes are usually in the nanometer range in such materials, we use the term nanocrystalline.
} 


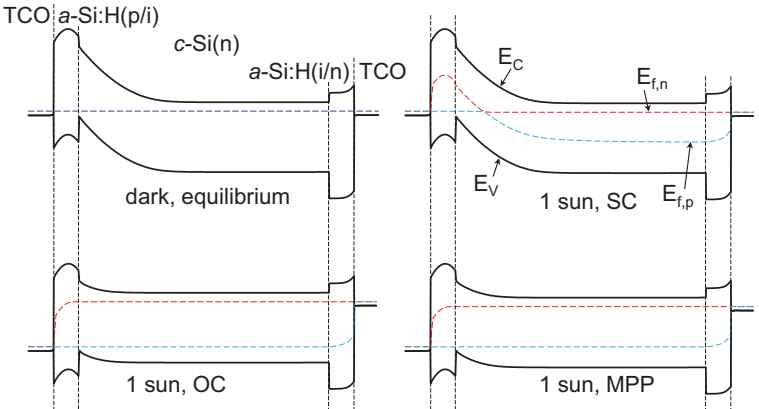

Fig. 5. Energy band diagrams of a SHJ device in equilibrium, short-circuit (SC), open-circuit (OC), and maximum power point (MPP) conditions. With the conduction band edge $E_{\mathrm{C}}$, valance band edge $E_{\mathrm{V}}$ and the quasi-Fermi-levels $E_{\mathrm{f}, \mathrm{n}}$ and $E_{\mathrm{f}, \mathrm{p}}$ for electrons and holes respectively.

\subsection{Alternative materials for contact formation}

In recent years a wide variety of novel materials have been investigated as carrier-selective contacts for silicon heterojunction solar cells. High-work-function metal-oxide lead the race for hole-selective contacts [84-87] whereas low-work-function metal-fluorides or even metals are highly investigated electron-selective contacts [88,87]. Most efficient devices use an intrinsic amorphous silicon layer for passivation $[84,87]$ though excellent results could also be obtained with simpler architectures, notably through the use of $\mathrm{TiO}_{2}$ as electron-selective contact [88].

A strong limitation of most electron-selective contact approach is the need to use a low-work-function metal as the electrode leading to severe parasitic absorption of the IR light. This absorption is due to the absence of a dielectric spacing layer between the silicon wafer and the metal, leading to strong plasmonic absorption [89]. This effect is worsened by the fact that low-work-function metals such as aluminum typically exhibit a poor reflection contrarily to e.g. gold or silver. Yet, the need to use such a low-workfunction metal to allow an efficient carrier-selective contact stack shows that not only the contact layer but also the electrode play a strong role in the selectivity of a contact stacks.

On the hole-selective contact side, the most successful material has been slightly substoichiometric molybdenum oxide $\left(\mathrm{MoO}_{\mathrm{x}}\right.$ with $\mathrm{x}$ close to 3) prepared by thermal evaporation. It is very notable that in this case, good solar cell results could be obtained even when this layer was capped with ITO, making it possible to exploit its transparency as a window layer. Its instability to post-deposition annealing, and to some extent to the electrode deposition make it difficult to integrate in



devices, though some strategies seem promising to enhance its robustness. Also, possibly due to the narrow window of (sub)stoichiometry for which adequate conductivity, work function, and possibly defect density are obtained, no other technique than thermal evaporation was successful so far in reaching similar efficiency as with evaporated material in spite of multiple attempts $[90,91]$. The stability is also a concern (and even more so) for electron contacts, with promising approaches usually incorporating $\mathrm{TiO}_{2}[87,88]$.

In addition to standard devices, IBC were also used for such contacts, with the possibility of very simple 2-evaporation-step processes, demonstrating remarkable efficiencies in spite of the absence of passivation layers [92]. Implementing a passivation layer, further improvements were made possible leading to even higher efficiencies [93].

Another approach closer to organics is the use of organic components, with PEDOT:PSS being the most successful hole-selective contact $[94,95]$, and dipole-inducing molecule being actively investigated as electron-selective contacts [96]. Such approaches have the advantage of typically not requiring a vacuum deposition tool, potentially enabling very inexpensive processing. Yet the use of liquid organic solutions is not straightforward on a textured surface, and the modest efficiencies shown so far do not appear sufficient to compete with traditional solar cell manufacturing solutions. The overall working principle of heterojunction solar cells using alternative materials appears still even more mysterious than silicon-based heterojunctions, with defect-assisted transport being thought as playing an important role [97].

\subsection{Temperature dependence: theoretical limits \& practical considerations}

In Fig. 7 we show the temperature dependence of $i V_{\mathrm{OC}}$ and $i F F$ as obtained from our simulations. We assumed a perfectly passivated absorber in this case $\left(D_{\mathrm{it}}=0 \mathrm{~cm}^{-2}\right) . i V_{\mathrm{OC}}$ and $i F F$ decrease both linearly with temperature, the relative temperature coefficients obtained from linear fitting are given in Table 1. As well-known from literature, the $\mathrm{TC}_{V_{\mathrm{OC}}}$ increases with increasing $V_{\mathrm{OC}}$ at $25^{\circ} \mathrm{C}$, the same holds true for $\mathrm{TC}_{\mathrm{FF}}$. The empirical models to describe $V_{\mathrm{OC}}(T)$ and $F F_{0}(T)$ proposed by Green [99] describes the observed trends well as long as the ideality factor is taken into account. For the comparison with experimental data, we included also temperature-dependent $V_{\mathrm{OC}}$ and $F F$ of a SHJ solar cell in the Figure. The experimental data has been published earlier [98]. While the $V_{\mathrm{OC}}$ of the experimental cell follows a linear trend as the simulated data, the $F F$ versus temperature curve is only linear for temperatures above $50^{\circ} \mathrm{C}$. This can be seen from the linear fit between $50^{\circ} \mathrm{C}$ and $65^{\circ} \mathrm{C}$ that we extrapolated to lower temperatures. For temperatures below $50^{\circ} \mathrm{C}$, the $F F$ is lower than the extrapolated straight

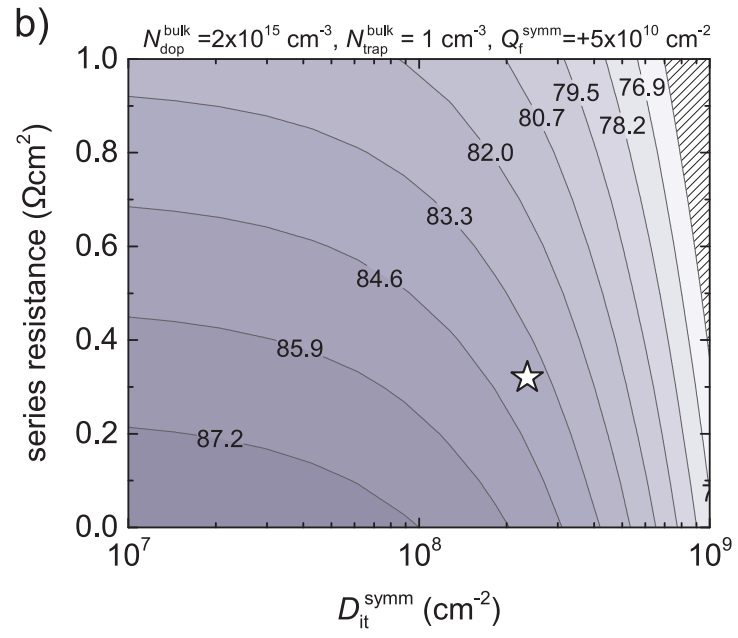

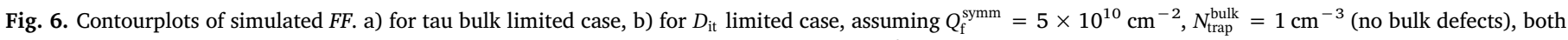
for $160 \mu \mathrm{m}$ n-type absorber. Star: data point of experimental IBC-SHJ device $\left(R_{\mathrm{S}}=0.32 \Omega \mathrm{cm}^{2}, F F=83.8 \%, \eta=26.3 \%\right)$ from ref. [10]. 


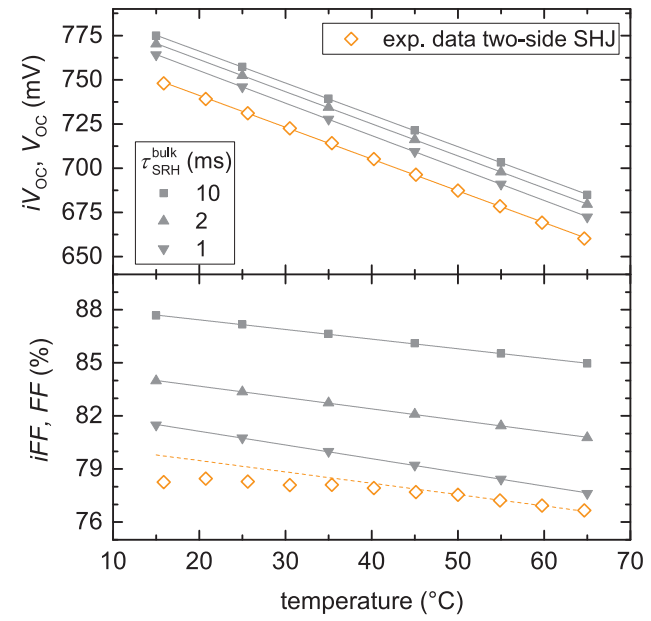

Fig. 7. Filled grey symbols: Simulated $i V_{\mathrm{OC}}$ and $i F F$ values versus temperature, assuming only recombination in the absorber. Orange open symbols: data of an experimental two-side SHJ solar cell, taken from ref. [98]. The solid lines are linear fits to the whole data range, the dashed line was fitted between $50^{\circ} \mathrm{C}$ and $65^{\circ} \mathrm{C}$, and then extrapolated for lower temperatures.

Table 1

Relative temperature coefficients of the data (simulation and experiment) shown in Fig. 7, obtained from linear fitting between $15^{\circ} \mathrm{C}$ and $65^{\circ} \mathrm{C}$. For the SHJ solar cell, the $\mathrm{TC}_{\mathrm{FF}}$ would amount to $-0.08 \% \mathrm{~K}^{-1}$, when fitted only in the linear range of the curve (between $50^{\circ} \mathrm{C}$ and $65^{\circ} \mathrm{C}$ ).

\begin{tabular}{llll}
\hline & $\begin{array}{l}a \mathrm{TC}_{V_{\mathrm{OC}}} \\
\mathrm{mVK}^{-1}\end{array}$ & $\begin{array}{l}\mathrm{TC}_{V_{\mathrm{OC}}} \\
\% \mathrm{~K}^{-1}\end{array}$ & $\begin{array}{l}\mathrm{TC}_{\mathrm{FF}} \\
\% \mathrm{~K}^{-1}\end{array}$ \\
\hline sim. $\tau_{\mathrm{SRH}}^{\text {bulk }}=10 \mathrm{~ms}$ & -1.80 & -0.24 & -0.06 \\
sim. $\tau_{\mathrm{SRH}}^{\text {bulk }}=2 \mathrm{~ms}$ & -1.81 & -0.24 & -0.08 \\
sim. $\tau_{\mathrm{SRH}}^{\text {bulk }}=1 \mathrm{~ms}$ & -1.83 & -0.25 & -0.10 \\
exp. SHJ cell & -1.81 & -0.25 & -0.05 \\
\hline
\end{tabular}

slope. This behavior is typical for SHJ solar cells [100,101,20,83] and due to thermally enhanced current transport. This temperature dependence leads to a deviation from classical models for ohmic carrier transport, and is also partly responsible for the high ${ }^{10} \mathrm{TC}_{\mathrm{FF}}$ reported for SHJ solar cells. However, in the case of the current world-record IBCSHJ solar cell $\left(\mathrm{FF}_{25^{\circ} \mathrm{C}}=84.9 \%\right)$, we expect this effect to be negligible, i.e. linear behavior for temperatures above $25^{\circ} \mathrm{C}$ in view of the very high $F F$ obtained at $25^{\circ} \mathrm{C}$. The remaining $\mathrm{R}_{\mathrm{s}}^{25^{\circ} \mathrm{C}}$ of probably ${ }^{11}$ below $0.2 \Omega \mathrm{cm}^{2}$ that could potentially be reduced at higher temperatures [102] is so low, that temperature-dependent transport should play only a minor role at typical operating conditions $\left(\vartheta>25^{\circ} \mathrm{C}\right)$. Deviation from linearity for the $F F$ might still occur but at temperatures lower than $25{ }^{\circ} \mathrm{C}$ for this device [20].

\section{SHJ solar modules}

Several companies (e.g. Panasonic Corp., Meyer Burger) already demonstrated that the good performances of SHJ solar cells can be translated into highly efficient solar modules. An important metric for module manufacturers is the so-called cell-to-module (CTM) power ratio which is

\footnotetext{
${ }^{10}$ The wording of high and low TC can be confusing as the TCs (except $\mathrm{TC}_{J_{\mathrm{SC}}}$ ) of silicon solar cells are usually negative. That means that a high absolute value of the TC is detrimental, but a high value (corresponding to a low absolute value) is beneficial for operation higher than $25^{\circ} \mathrm{C}$.

11 The device with the highest efficiency (26.7\%) has so far been only reported in the efficiency Tables 50 [35], where no value for $R_{\mathrm{S}}$ is given. We assume that with an $R_{\mathrm{S}}$ of $0.2 \Omega \mathrm{cm}^{2}$ for a device with a FF of $84.6 \%$ [1], $R_{\mathrm{S}}$ is probably even below $0.2 \Omega \mathrm{cm}^{2}$ for the new record.
}

the module power divided by the sum of the power of its constituent cells. CTM power ratios can vary greatly depending on module type and features, e.g. white backsheet modules benefit from $a \approx 2 \%$ gain in short circuit current $\left(I_{\mathrm{SC}}\right)$ because of the light recollected after reflection on the backsheet between the cells $[103,104]$. Advanced interconnection techniques and improvements in light management at the module level are pushing CTM factors upward and they are expected to exceed $100 \%$ by 2020 [105]. There is a number of CTM loss and gain mechanisms (see e.g. $[106,107])$ and it is interesting to identify those that affect the $I_{\mathrm{SC}}$ and those that affect the $F F$ of modules.

The main optical loss phenomena is the reflection caused by the refractive index mismatch at the glass/air interface, for standard solar glass this is about $4 \%$. Different ARC layers can be used to reduce this loss, e.g. a porous $\mathrm{SiO}_{2}$ layer coated onto solar glass using industrial solgel processes increases $I_{\mathrm{SC}}$ by about $2.7 \%$ [108]. Another $I_{\mathrm{SC}}$ loss is caused by parasitic absorption in the encapsulant and can also take a range of values as there is a number of different encapsulants on the market with various optical properties and different stabilities e.g. to UV. The encapsulant has also a small positive effect on $I_{\mathrm{SC}}$, about $+0.3 \%$, as it acts like a dual-layer ARC. Additionally, as mentioned in Section 2, this implicates a lower TCO thickness to minimize reflection. ${ }^{12}$ Another optical benefit from the encapsulation of solar cells is the recollection of the fraction of light reflected on the metallization that is redirected onto the cell by total internal reflection at the glass/ air interface. This so-called optical coupling reduces the effective shading by the fingers by about $50 \%$ (depending on the finger shape) which in turn boosts $I_{\mathrm{SC}}$ by about $1.5 \%$. This light recollection mechanism is also important in reducing the shading by the interconnection and depends on the interconnection shape. For example, the effective shading of textured ribbons is typically half that of standard ribbons (this corresponds to an $I_{\mathrm{SC}}$ gain around $1 \%$ ). In multi-wire configurations, in which the cell-interconnecting ribbons are replaced by round wires, the effective optical shading is only $\approx 60 \%$ of the wire diameter thanks to its circular shape.

The main mechanism that affects the module $F F$ is the ohmic loss in the cell interconnections (ribbons or wires), between the strings, in the junction boxes and in the cabling. The main loss stemming from the cell interconnection whose design is driven by a trade-off between shading and ohmic losses as well as, for the industry, the price of metal and the extra cost of features such as textured ribbons. To illustrate this, we simulate (see the details in Appendix B) the losses for two multi-wires configurations with different diameters: $250 \mu \mathrm{m}$ and $300 \mu \mathrm{m}$. The thicker wires cause more shading than their thinner counterparts $(2.1 \%$ versus $1.7 \%$ ), but they also reduce series resistance so the ohmic loss is significantly reduced (1.8\% versus $2.7 \%)$. All in all, the $300 \mu \mathrm{m}$ configuration enables a better CTM power factor, $+0.5 \%$, and the final choice is then driven by economic considerations. Additionally, the climate where the modules are to be operated can be taken into consideration in order to maximize energy yields. For example, in very sunny and hot climates, it might be beneficial to lower $R_{\mathrm{S}}$ even at the expense of $I_{\mathrm{SC}}$ while the opposite might be true for a module operating at a location where the average incident irradiation is well below $1000 \mathrm{~W} \mathrm{~m}^{-2}$ [98].

The FF of a module is also affected by the so-called cell-to-cell mismatch loss, which originates from the connection in series of cells with different IV characteristics [109]. While it has been shown that, for modern industries, the cell-to-cell mismatch has a negligible effect on module power even without any cell binning $[110]^{13}$, it has nevertheless an interesting two-sided effect on module $F F$ and $I_{\mathrm{SC}}$. Fig. 8a exemplifies that the $I_{\mathrm{SC}}$ of 60 cells connected in series is

\footnotetext{
${ }^{12}$ Note that the actual optimal TCO thickness remains a trade-off between anti-reflection, transparency and lateral conduction which depends upon the chosen metallization design.

13 This study is based on IV data from 10,000 cells from a production order in 2012 from a Suntech manufacturing facility in China.
} 
systematically lower than the average $I_{\mathrm{SC}}$ of these cells (closer to the minimum $I_{\mathrm{SC}}$ ). On the other hand, the $F F$ of the serially-connected cells is larger than the average $F F$ of the cells. This phenomena is important to correctly analyze the CTM factors of modules even when the cell-tocell mismatch is small. This is illustrated on Fig. 8b where the distributions of the CTM factors of power, $F F$ and $I_{\mathrm{SC}}$ are shown of 5000 simulated modules comprised of cells with $I_{\mathrm{SC}}$ in a $4 \%$ range. While the loss in power is low $\left(\mathrm{CTM}_{P_{\mathrm{mpp}}}\right.$ around -0.15\%), the cell-to-cell mismatch causes a strong negative $\mathrm{CTM}_{\mathrm{ISC}_{\mathrm{SC}}}(\approx-1 \%)$ partially counterbalanced by a positive $\mathrm{CTM}_{\mathrm{FF}}(\approx+0.85 \%)$ [104]. This effect is important for a module manufacturer to accurately separate between ohmic and optical losses (e.g. a good $F F$ does not necessarily mean small resistive losses if the cell-to-cell mismatch in a particular module is large).

\section{Industrial aspects}

Sanyo Corp. (now Panasonic Corp.) was the first company to commercialize SHJ solar cells, and produced for many years some of the most efficient $c$-Si modules with the lowest temperature coefficient [111]. In the last few years, several companies have launched pilot production, or even mass production of SHJ solar cells. Some companies recycled parts of the equipment $\mathrm{s}$ designed for the production of thin film silicon solar cells for depositing some of the SHJ layers. In parallel, several companies have started to design equipments specific for the manufacturing of SHJ solar cells and modules. The coating technologies include hot-wire and (parallel plate) PECVD for the $a$-Si:H layers and sputtering or ion plating ${ }^{14}[112,113]$ for the TCO deposition. For metallization, screen-printing of low-temperature silver paste, or plating can be applied. The lean standard SHJ process (cf. Fig. 9) ensures that only few pieces of equipment are required (wet chemical preparation of the wafer, PECVD reactor for $a$-Si:H layers, PVD for TCO, screen-printing for the metallization, annealing) and has a potential to come both in terms of capital expenditures (CAPEX) and operational expenditures (OPEX) to a level similar to those of competing PERC technologies. Considering the potential of a high bifaciality factor (>90\%) [114], record low temperature coefficient and high energy yield $^{15}[116]$, thinner wafer for lower costs, SHJ bears the potential to achieve ultra-low electricity costs. A mass market entrance has been delayed though by many negative perceptions with respect to the difficulty of the technology, which we discuss here below:

- Passivation homogeneity: A major perceived difficulty is the achievement of homogeneous ultra-thin passivation layers based on $a$-Si:H in PECVD reactors, which might prevent the achievement of high production yield. Indeed, such issues can be solved, e.g. by working on the PECVD reactor design [117-121]. The concept of closed heated plasma box $[117,120]$ enables for example to solve two major issues:

i) suppression of strong species diffusion near the edges of the reactor, which would occur in open reactors when the plasma is ignited and would lead to surface passivation inhomogeneity.

ii) suppression of cross-contamination linked to the cleaning of the reactor, only required after some hundred or thousands of coating cycles.

- Availability of high-quality n-type silicon wafers at a competitive price: A large fraction of the PV industry uses p-type wafers, raising the question of the availability of high-quality n-type

\footnotetext{
${ }^{14}$ Ion plating is also referred to as high density plasma-enhanced evaporation.

${ }^{15}$ Using $\Delta E Y=\Delta \mathrm{TC} \cdot\left(T_{\mathrm{avg}}-T_{\mathrm{STC}}\right)$, gains in energy yield stemming from advantageous temperature coefficients can be estimated if the average operating temperature in terms of energy production expected in a given location, $T_{\text {avg }}$, is known. For example, $T_{\text {avg }}$ can reach $50^{\circ} \mathrm{C}$ in desert areas in the American Southwest [115] which means that a reduction of temperature coefficient of $0.1 \% / \mathrm{K}$ results in an energy yield gain of $2.5 \%$ in such locations.
}

material. Yet in recent years, triggered by the demand for higher $\mathrm{p}$ type material quality from the PERC market, most monocrystalline silicon ingot manufacturer developed know-how enabling them to also grow high quality full n-type ingots (e.g. typically with a lifetime/resistivity above $1 \mathrm{~ms} / \Omega \mathrm{cm}$ ) at cost similar or only slightly superior to those of p-type materials [122]. Additionally, even in the case of multiple-charge pulls, metallic impurities and oxygen concentration can be kept at concentration sufficiently low for achieving high lifetime absorber material, without additional thermal donor treatment or gettering. A slightly higher price for $n$ type wafers compared to p-type wafers still come from less recharge of the quartz crucible than for p-type materials (a problem on which companies are working), and can be fully compensated by the use of thinner wafers possible for SHJ [122].

- Risk of high metallization costs: Because of the final annealing step at around $200{ }^{\circ} \mathrm{C}$, low-curing-temperature (low-T) silver pastes are used. First generations of such low-T pastes exhibited a much lower conductivity than the pastes sintered for standard cells at over $800^{\circ} \mathrm{C}$ (up to a factor 10 , in the late 2000 's). Thanks to the continuous improvement in the paste development [114], illustrated in Fig. 10, modern pastes are coming closer to bulk $\mathrm{Ag}$, with resistivities in the range of $5-6 \mu \Omega \mathrm{cm}$. This is fully compatible with the current cell configurations featuring five or six busbars, and minimum amount of paste consumption $[123,124]$. With the use of multi-wire configurations, in which the ribbons are replaced by round wires, the demand on finger conductance is further decreased [114]: typcially 18 wires of $\sim 300 \mu \mathrm{m}$, embedded into a polymer foil, solder on the soft $\mathrm{Ag}$ paste during the lamination process. Because of the very short distance between two wires, a potential to reduce the $\mathrm{Ag}$ consumption down to $10-20 \mathrm{mg}$ per side of 6 -in. cells has been reported [123]. To entirely suppress the need for silver, copper plating has also been reported as an alternative approach, and Fig. 11 shows a possible process to realize directly a bifacial $\mathrm{Cu}$ metalization $[48,114,125]$ which then has a low cost potential upon large-scale acceptance.

- Risk of high costs of TCO: typically $80 \mathrm{~nm}$ of TCO are deposited at the front and back of the SHJ. ITO targets are a major cost factor, corresponding typically to a usage of around $3.5 \mathrm{~g}$ of Indium per $\mathrm{m}^{2}$ of modules for both surfaces (taking into account a 50\% usage of the sputtered materials). Without even considering the recycling of In deposited on the carriers and in the chamber, the cost of In is hence currently in the range of an acceptable $1 \$ / \mathrm{m}^{2}$ [126], corresponding, for a $335 \mathrm{~W} 60$-cell module, to below $0.005 \$ / \mathrm{W}$. Alternative TCO such as Zinc oxide $(\mathrm{ZnO})$ can also be used, in particular on the n-side, where the wafer-bulk conductivity plays a major role. For the configuration with p-layer on the front, a thin high-mobility TCO can be used combined with a lower-cost TCO to divide altogether the In consumption by a factor 4 (and 8 if Indium is recycled from the chamber walls). Hence this does not constitute a more fundamental problem than e.g. the use of $\mathrm{Ag}$ paste in standard $\mathrm{c}$ Si cells and modules.

With the development of modern coating hardware [127,128], highly efficient and cost-effective metallization scheme, the industry should have now many cards at hands to launch high volume manufacturing of SHJ. Indeed, six inch SHJ solar cells made in a pilot line were certified at $24 \%$, in the so-called busbar-less configuration (i.e. without wire shading and without resistive losses in the wires, corresponding to $>23 \%$ for full six inch devices) [129]. Modules using standard M2 SHJ cells produced in the same pilot line, multi-wire interconnection and with regular cell spacing were certified at $335 \mathrm{~W}$ [129], a value well above today s standard PV module performance (cf. Fig. 12). The modules show a remarkable $F F$ of $79.4 \%$. SHJ modules are free from potential induced degradation (PID), and with the right choice of module technology, a performance loss of less than $10 \%$ after 25 years can be guaranteed (e.g. on Panasonic N330). Combined with 
a)

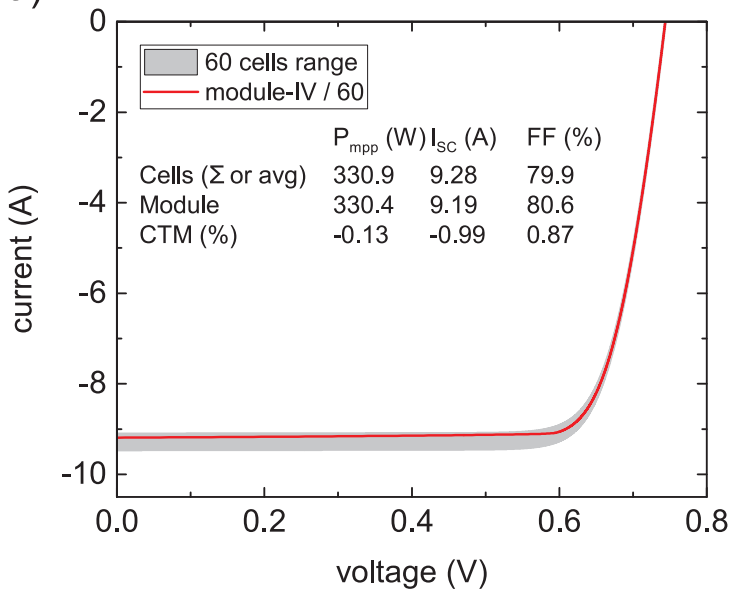

b)

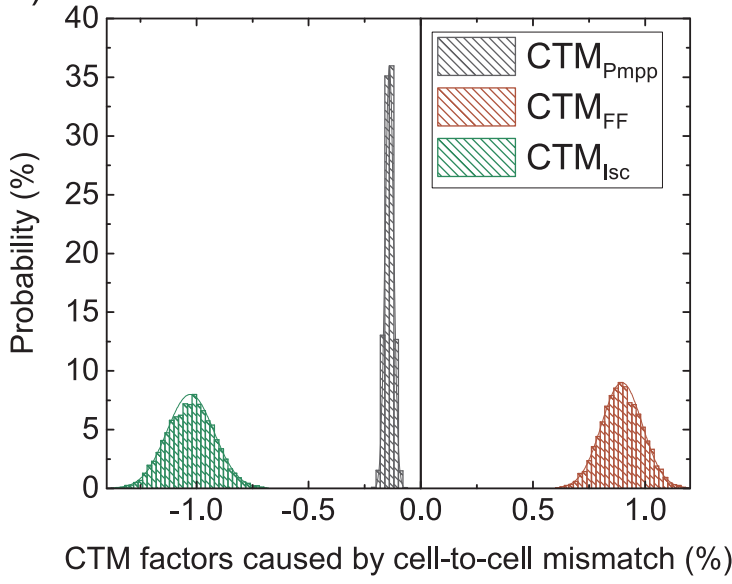

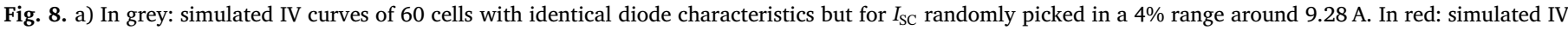

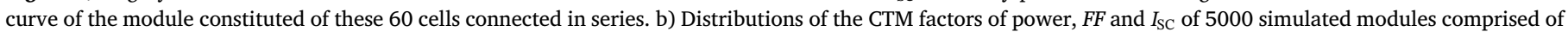
cells with $I_{\mathrm{SC}}$ in a $4 \%$ range from ref. [104].

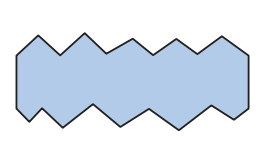

1. cleaning
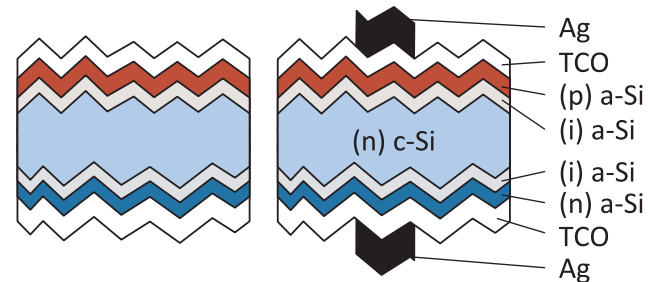

3. TCO deposition

4. metallisation

Fig. 9. Manufacturing steps of a bifacial silicon heterojunction solar cell.

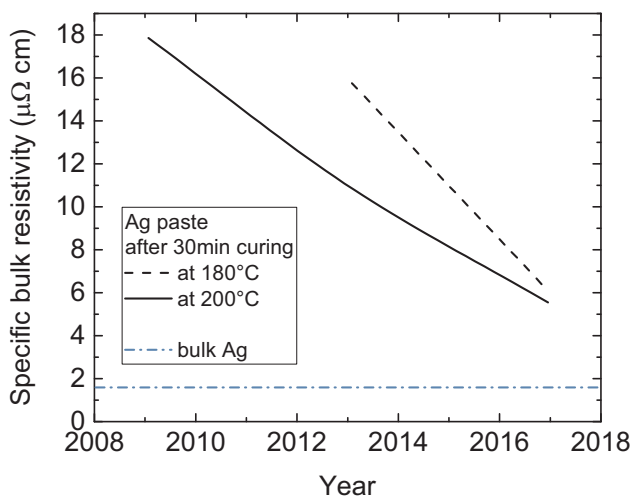

Fig. 10. Specific bulk resistivity of low-temperature Ag paste as a function of the year. Pure silver (horizontal line) is included as well for comparison. The continuous line indicates the resistivity after $30 \mathrm{~min}$ of curing at $200{ }^{\circ} \mathrm{C}$, whereas the dashed line is obtained after curing $30 \mathrm{~min}$ at $180{ }^{\circ} \mathrm{C}$. Data courtesy of Namics Corp.

the expected high energy yield and the quasi perfect bifaciality this should lead to record high kWh production per rated $W_{\mathrm{P}}$ in many environments. Finally, IBC-SHJ devices could further extend the efficiency and performance roadmap of SHJ, provided that the efficiency gain compensates for the increased process complexity. Both highest

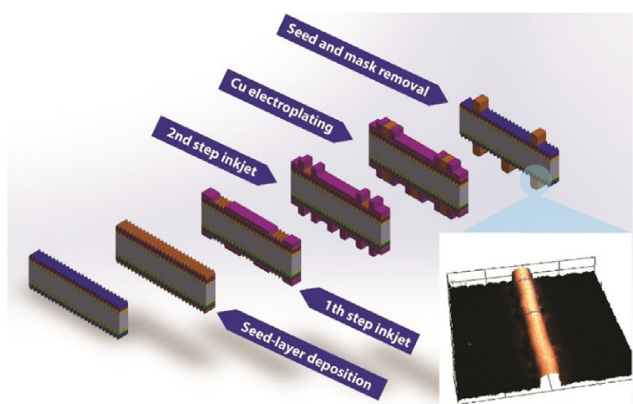

Fig. 11. Process-flow of copper electroplating for a bifacial SHJ solar cell. Image courtesy of J. Geissbühler, CSEM [48,125].

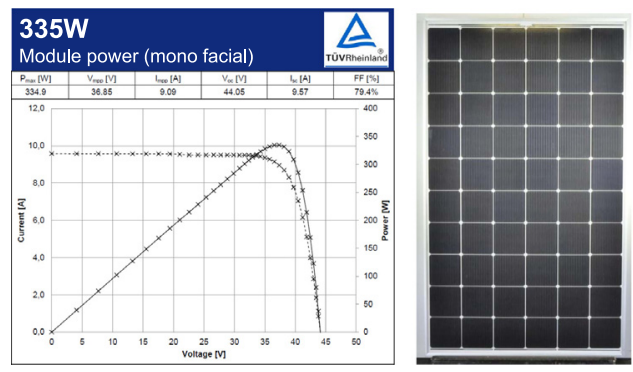

Fig. 12. Certified IV characteristic of a 60-cells (M2) module integrating SHJ solar cells and a white back-foil. The peak power of the module is $335 \mathrm{~W}$. The cells were processed in the pilot-line of the Meyer Burger group in Hohenstein (DE) and the multi-wire interconnection is a new generation one, co-developed between CSEM and Meyer Burger Thun (CH). It uses wires without indium, allowing for low assembly and metallization costs. This is the highest reported performance for a module of this type.

efficiency $[1,4]$ and lean processes have been reported [34] but not yet in the same device.

\section{Summary}

Silicon heterojunction (SHJ) solar cells are part of the family of solar cells with passivating contacts; they feature high open-circuit voltages $\left(V_{\mathrm{OC}}\right)$, generally well above $700 \mathrm{mV}$. Achieving of fill-factors $(F F)$ comparable to the best high-efficiency devices based on homo-junctions has long been a challenge for SHJ solar cells. In 2017, Kaneka Corp. 
demonstrated a SHJ solar cell with interdigitated contacts at the rear side with a $F F$ of $84.9 \%$, the highest ever shown for a silicon solar cell so far. With an efficiency of $26.7 \%$ this marked a new world record for silicon solar cells, and it underlines that SHJ technology not only enables very high $V_{\mathrm{OC}}$, but also $F F$. In a simulation study we show the impact of recombination in the absorber as well as at its surfaces on $V_{\mathrm{OC}}$ and $F F$ and emphasize that low recombination is especially important to reach high FF. We review briefly the different cell-to-module loss and gain mechanisms. For different interconnection schemes we discuss the trade-off between shading and resistive losses, and discuss FF gains that can arise from cell-to-cell mismatch. Regarding industrialization, the homogeneity of the thin $a$-Si:H passivation layers as well as expensive raw materials were often seen as hindrances for the success of SHJ. With recent technological progress, these problems will likely be solved in the future. The intrinsic bifacial nature of SHJ technology as well as its low temperature coefficient should lead to record high energy production per rated power in many climate regions.

\section{Acknowledgements}

The authors gratefully acknowledge the support of the Qatar Foundation for funding. Raphaël Monnard and Gabriel Christmann, for support in developing the python script, Jacques Levrat for help with the CTM simulations, and Peter Fiala for proofreading abstract and summary. This project has received funding from the European Union's Horizon 2020 research and innovation programmes under Grant Agreements $\mathrm{N}^{\circ} 727529$ (Disc), $\mathrm{N}^{\circ} 727523$ (NextBase), and $\mathrm{N}^{\circ} 745601$ (Ampere).

\section{Appendix A. Description of simulation approach}

For the simulation of (temperature-dependent) JV characteristics a python script was developed to calculate:

1. injection-dependent effective minority carrier lifetime, considering Shockley-Read-Hall, Auger and radiative recombination in the silicon absorber as well as surface recombination;

2. the absorbed current density $J_{\text {abs }}$ for the AM1.5 g (ASTM G-173-03) spectrum at a given temperature and optical properties;

3. the implied JV characteristic from the injection-dependent effective minority carrier lifetime, assuming $J_{\text {abs }}$ as short circuit current density;

4. the JV characteristic assuming an ohmic series resistance by shifting the voltage according to the voltage drop over the resistance at the given current density following Ohm's law.

\section{A.1. Optical modeling}

The calculation of the absorption $A(\lambda)$ is done using analytical modeling, following an approach initially suggested by Deckman et al. [130] and extended by Boccard et al. [131]. The analytical model traces an average ray through the absorber and assumes a lambertian distribution of light. We use Eq. (5) in ref. [131] to calculate the absorption in the wavelength-range from $300 \mathrm{~nm}$ to $1300 \mathrm{~nm}$. We assume no reflection when entering the absorber $\left(R_{0}=0\right)$. For the simulations shown in Fig. 4, we vary the parasitic absorption at the rear side as a wavelength-independent parameter $\left(A_{\mathrm{P}}^{\text {back }}=0,0.1,0.25,0.5\right)$. The parasitic absorption at the front side $\left(A_{\mathrm{P}}^{\text {front }}\right)$ we calculate with single-pass Lambert-Beer absorption

$A_{\mathrm{P}}^{\text {front }}=1-\exp \left(-\frac{4 \pi k_{\mathrm{aSi}}}{\lambda} \cdot t_{\mathrm{aSi}}\right)$

for $a$-Si:H(p) thicknesses $t_{\mathrm{aSi}} 0 \mathrm{~nm}, 2 \mathrm{~nm}, 5 \mathrm{~nm}, 10 \mathrm{~nm}$, and with the extinction coefficient for $a$-Si:H(p) $k_{\mathrm{aSi}}(\lambda)$ published by Holman et al. [53] and taken from the refractive index library on pvlighthouse.com. Further parameters of the optical models are: $a_{0}=2, b_{1}=1 / n^{2}$ (lambertian scattering), and the temperature dependent absorption coefficient of silicon $\alpha(T)$, taken from ref. [132]. Using $A(\lambda)$, the absorbed current density $J_{\text {abs }}$ is then calculated following

$J_{\text {abs }}=\frac{q}{h c} \int_{300 \mathrm{~nm}}^{1300 \mathrm{~nm}} A(\lambda) \cdot \lambda E_{\mathrm{AM} 1.5}(\lambda) d \lambda$

with the elementary charge $q$, the Planck constant $h$, and the speed of light $c$.

\section{A.2. Charge carrier lifetime \& implied JV curve modeling}

Recombination in the silicon absorber is characterised by Shockley-Read-Hall lifetime $\tau_{\mathrm{SRH}}^{\text {bulk }}$ [133], equation (5.3) and intrinsic lifetime $\tau_{\text {intr }}$ as parametrized by Richter et al. [134], equation (18). For the temperature-dependent intrinsic carrier concentration $n_{\mathrm{i}}(T)$ the parametrization by Misiakos et al. [135] is used.

The surface recombination rate $R_{\text {surf }}$ is modeled using the model for $a$-Si:H/c-Si interface recombination based on the amphoteric nature of silicon dangling bonds proposed by Olibet et al. [136]. The parameters used in the model are summarized in Table A1, the same surface recombination has been assumed for both sides of the absorber.

Table A1

Parameter used for the simulation if not stated otherwise.

\begin{tabular}{llll}
\hline $\begin{array}{l}\text { Parameter } \\
\text { (bulk) }\end{array}$ & Value & $\begin{array}{l}\text { Parameter } \\
\text { (surface) }\end{array}$ & Value \\
\hline Wafer thickness $w$ & $160 \mu \mathrm{m}$ & Model & $\begin{array}{l}\text { Dangling-bond } \\
\text { Doping (n-type) }\end{array}$ \\
$\sigma_{\mathrm{n}}$ & $2 \times 10^{15} \mathrm{~cm}^{-3}$ & $Q_{\mathrm{g}}$ & $0 \mathrm{~cm}^{-2}$ \\
$\sigma_{\mathrm{p}}$ & $10^{-14} \mathrm{~cm}^{2}$ & $\sigma_{\mathrm{n}}^{0}$ & $\frac{1}{20} \cdot 10^{-16} \mathrm{~cm}^{2}$ \\
$N_{\text {truap }}^{\text {bulk }}$ & $10^{-14} \mathrm{~cm}^{2}$ & $\sigma_{\mathrm{p}}^{0}$ & $10^{-16} \mathrm{~cm}^{2}$ \\
Trap energy level & $10^{9} \mathrm{~cm}^{-3}$ & $\sigma_{n}^{+}$ & $500 \cdot \sigma_{\mathrm{n}}^{0}$ \\
\end{tabular}


The injection-dependent effective lifetime $\tau_{\text {eff }}$ is then calculated with $\tau_{\mathrm{SRH}}^{\text {bulk }}, \tau_{\text {intr }}$, and assuming symmetrical surface recombination [137] following $\frac{1}{\tau_{\text {eff }}}=\frac{1}{\tau_{\mathrm{SRH}}^{\text {bulk }}}+\frac{1}{\tau_{\text {intr }}}+\frac{2 R_{\text {surf }}}{\Delta n w}$

with the excess charge carrier density $\Delta n$ and absorber thickness $w$. When the effective lifetime should be limited by surface recombination only, the bulk defect density was set to $1 \mathrm{~cm}^{-3}$ to avoid division by zero.

The implied open-circuit voltage $V_{\mathrm{OC}}\left(i V_{\mathrm{OC}}\right)$ is dependent of $\Delta n$ and is calculated using

$i V_{\mathrm{OC}}(\Delta n)=\frac{k T}{q} \ln \left(\frac{\left(n_{0}+\Delta n\right)\left(p_{0}+\Delta p\right)}{n_{\mathrm{i}}(T)^{2}}\right)$

with the Boltzmann constant $k$, and the equilibrium concentrations of electrons $\left(n_{0}\right)$ and holes $\left(p_{0}\right)$, and $\Delta n=\Delta p$. The implied voltage range $i V_{\mathrm{OC}}(\Delta n)$ represents the voltage of the implied JV characteristic.

The recombination current $J_{\text {rec }}(\Delta n)$ can be written as

$J_{\text {rec }}(\Delta n)=q w \frac{\Delta n}{\tau_{\text {eff }}}$

which leads to the implied JV characteristic derived for a range of $\Delta n$. For the calculation of the illuminated implied JV characteristic, the $J_{\text {abs }}$ as obtained from equation (A.2) is assumed as $J_{\mathrm{SC}}$ and subtracted from the right side of equation (A.5) which allows for the calculation of the implied fill-factor $i F F$.

\section{Appendix B. Comparison of cell-to-module losses of two multi-wire configurations: $200 \mu \mathrm{m}$ and $300 \mu \mathrm{m}$}

This simulation aims at illustrating the trade off between shading and ohmic losses that drives the choice of an interconnection scheme.

Because of their circular shape, the effective optical shading of wires once encapsulated in modules is about $60 \%$ of the wire diameter $\left(\phi_{\text {wires }}\right){ }^{16}$ Then, the shading loss can be estimated using:

shading $=N_{\text {wires }} \cdot \phi_{\text {wires }} \cdot 0.6 \cdot \frac{\text { length }}{\text { arell }}$

with e.g. for $6 \mathrm{in}$. M2 wafers, length cell $_{1}=156.75 \mathrm{~mm}$ and area $_{\text {cell }}=244.3 \mathrm{~cm}^{-2}$.

The ohmic losses in the interconnection were calculated using an in-house simulation software. The parameters for the simulation were chosen to be representative of a standard bifacial multi-wire SHJ configuration: wire resistivity $(1.7 \mu \Omega \mathrm{m})$, number of fingers at the front and the rear ( 87 and 207), and finger line resistance at the front and the rear $\left(0.83\right.$ and $\left.0.91 \Omega \mathrm{cm}^{-1}\right)$.

\section{References}

[1] K. Yoshikawa, W. Yoshida, T. Irie, H. Kawasaki, K. Konishi, H. Ishibashi, T. Asatani, D. Adachi, M. Kanematsu, H. Uzu, K. Yamamoto, Exceeding conversion efficiency of $26 \%$ by heterojunction interdigitated back contact solar cell with thin film Si technology, Sol. Energy Mater. Sol. Cells 173 (2017) 37-42, https://doi. org/10.1016/j.solmat.2017.06.024 〈http://linkinghub.elsevier.com/retrieve/pii/ S092702481730332X >.

[2] K. Masuko, M. Shigematsu, T. Hashiguchi, D. Fujishima, M. Kai, N. Yoshimura, T. Yamaguchi, Y. Ichihashi, T. Mishima, N. Matsubara, T. Yamanishi, T. Takahama, M. Taguchi, E. Maruyama, S. Okamoto, Achievement of more than $25 \%$ conversion efficiency with crystalline silicon heterojunction solar cell, IEEE J. Photovolt. 4 (6) (2014) 1433-1435, https://doi.org/10.1109/JPHOTOV.2014. 2352151.

[3] F. Haase, R. Peibst, $26.1 \%$ record efficiency for p-type crystalline Si solar cells (2018). URL 〈https://isfh.de/en/26-1-record-efficiency-for-p-type-crystalline-sisolar-cells $>$.

[4] M.A. Green, Y. Hishikawa, E.D. Dunlop, D.H. Levi, J. Hohl-Ebinger, A.W. HoBaillie, Solar cell efficiency tables (version 51), Progress. Photovolt.: Res. Appl. 26 (1) (2018) 3-12, https://doi.org/10.1002/pip.2978 〈http://doi.wiley.com/10. 1002/pip.2978>.

[5] J. Nakamura, N. Asano, T. Hieda, C. Okamoto, H. Katayama, K. Nakamura, Development of heterojunction back contact Si solar cells, IEEE J. Photovolt. 4 (6) (2014) 1491-1495, https://doi.org/10.1109/JPHOTOV.2014.2358377.

[6] D.D. Smith, P. Cousins, S. Westerberg, R.D. Jesus-Tabajonda, G. Aniero, Y.C. Shen, Toward the practical limits of silicon solar cells, IEEE J. Photovolt. 4 (6) (2014) 1465-1469, https://doi.org/10.1109/JPHOTOV.2014.2350695 〈http:// ieeexplore.ieee.org/document/6895145/ >.

[7] T. Kinoshita, D. Fujishima, A. Yano, A. Ogane, S. Tohoda, K. Matsuyama, Y. Nakamura, N. Tokuoka, H. Kanno, H. Sakata, M. Taguchi, E. Maruyama, The Approaches for High Efficiency HIT Solar Cell with Very Thin $(<100 \mu \mathrm{m})$ Silicon Wafer over 23\%, in: Proceedings of the 26th European Photovoltaic Solar Energy Conference and Exhibition, 2011, pp. 871-874. doi:10.4229/26thEUPVSEC20112AO.2.6.

[8] J. Zhao, A. Wang, S.J. Robinson, M.A. Green, Reduced temperature coefficients for recent high-performance silicon solar cells, Prog. Photovolt.: Res. Appl. 2 (3) (1994) 221-225, https://doi.org/10.1002/pip.4670020305 〈http://doi.wiley. com/10.1002/pip.4670020305 >.

[9] M. Taguchi, A. Yano, S. Tohoda, K. Matsuyama, Y. Nakamura, T. Nishiwaki, K. Fujita, E. Maruyama, 24.7\% Record efficiency HIT solar cell on thin silicon wafer, IEEE J. Photovolt. 4 (1) (2014) 96-99, https://doi.org/10.1109/JPHOTOV. 2013.2282737.

[10] K. Yoshikawa, H. Kawasaki, W. Yoshida, T. Irie, K. Konishi, K. Nakano, T. Uto, D. Adachi, M. Kanematsu, H. Uzu, K. Yamamoto, Silicon heterojunction solar cell with interdigitated back contacts for a photoconversion effciency over $26 \%$, Nat Energy 2 (17032) (2017) 10.1038/nenergy.2017.32.

[11] D. Adachi, J.L. Hernández, K. Yamamoto, Impact of carrier recombination on fill factor for large area heterojunction crystalline silicon solar cell with $25.1 \%$ efficiency, Appl. Phys. Lett. 107 (23) (2015) 233506, https://doi.org/10.1063/1. 4937224.

[12] S. De Wolf, A. Descoeudres, Z.C. Holman, C. Ballif, High-efficiency Silicon Heterojunction Solar Cells: a Review, Green 2 (1) (2012) 7-24, https://doi.org/10. 1515/green-2011-0018.

[13] C. Ballif, S. De Wolf, A. Descoeudres, Z.C. Holman, Amorphous Silicon/Crystalline Silicon Heterojunction Solar Cells, 1st ed., 90 Elsevier Inc., 2014, https://doi.org/ 10.1016/B978-0-12-388417-6.00003-9.

[14] M. Leilaeioun, Z.C. Holman, Accuracy of expressions for the fill factor of a solar cell in terms of open-circuit voltage and ideality factor, J. Appl. Phys. 120 (12) (2016) 123111, https://doi.org/10.1063/1.4962511 〈http://aip.scitation.org/ doi/10.1063/1.4962511 >.

[15] A. Descoeudres, Z.C. Holman, L. Barraud, S. Morel, S. De Wolf, C. Ballif, 21\% efficient silicon heterojunction solar cells on n-and p-type wafers compared, IEEE J. Photovolt. 3 (1) (2013) 83-89, https://doi.org/10.1109/JPHOTOV.2012. $2209407\langle$ http://ieeexplore.ieee.org/xpls/abs_all.jsp?arnumber $=6263260\rangle$ 〈http://ieeexplore.ieee.org/ielx5/5503869/6387608/06263260.pdf?tp = \& arnumber $=6263260$ \&isnumber $=6387608\rangle$.

[16] I. Shoukry, J. Libal, R. Kopecek, E. Wefringhaus, J. Werner, Modelling of bifacial gain for stand-alone and in-field installed bifacial PV modules, Energy Procedia 92 (2016) 600-608, https://doi.org/10.1016/j.egypro.2016.07.025 〈http://dx.doi. org/10.1016/j.egypro.2016.07.025 >.

[17] X. Sun, M.R. Khan, C. Deline, M.A. Alam, Optimization and performance of bifacial solar modules: a global perspective, Appl. Energy 212 (2017) 1601-1610, https://doi.org/10.1016/j.apenergy.2017.12.041 〈http://arxiv.org/abs/1709. $10026>$.

[18] A. Cuevas, D. Yan, Misconceptions and misnomers in solar cells, IEEE J. Photovolt.

\footnotetext{
${ }^{16}$ Effective optical shading can be measured on encapsulated samples using the laser beam induced current (LBIC) technique for example.
} 
3 (2) (2013) 916-923, https://doi.org/10.1109/JPHOTOV.2013.2238289 〈http://ieeexplore.ieee.org/ielx5/5503869/6481434/06420858.pdf?tp = \& arnumber $=6420858$ \&isnumber $=6481434>$.

[19] M. Bivour, H. Steinkemper, J. Jeurink, S. Schröer, M. Hermle, Rear emitter silicon heterojunction solar cells: fewer restrictions on the optoelectrical properties of front side TCOs, Energy Procedia 55 (2014) 229-234, https://doi.org/10.1016/J. EGYPRO.2014.08.035 〈http://www.sciencedirect.com/science/article/pii/ S1876610214012594 〉.

[20] G. Nogay, J.P. Seif, Y. Riesen, A. Tomasi, Q. Jeangros, N. Wyrsch, F.J. Haug, S. De Wolf, C. Ballif, Nanocrystalline silicon carrier collectors for silicon heterojunction solar cells and impact on low-temperature device characteristics, IEEE J. Photovolt. 6 (6) (2016) 1654-1662, https://doi.org/10.1109/JPHOTOV.2016. 2604574.

[21] K. Yamamoto, D. Adachi, H. Uzu, M. Ichikawa, T. Terashita, T. Meguro, N. Nakanishi, M. Yoshimi, J.L. Hernández, High-efficiency heterojunction crystalline Si solar cell and optical splitting structure fabricated by applying thin-film Si technology, Jpn. J. Appl. Phys. 54 (8S1) (2015), https://doi.org/10.7567/JJAP. 54.08KD15 08KD15. URL 〈http://stacks.iop.org/1347-4065/54/i = 8S1/a = 08KD15?key $=$ crossref.683d0a8b0eb3dcd9c1f1cb1950ab53cd $\rangle\langle$ http:// iopscience.iop.org/article/10.7567/JJAP.54.08KD15/pdf $>$.

[22] R. Varache, J. Kleider, M. Gueunier-Farret, L. Korte, Silicon heterojunction sola cells: optimization of emitter and contact properties from analytical calculation and numerical simulation, Mater. Sci. Eng.: B 178 (9) (2013) 593-598, https:// doi.org/10.1016/J.MSEB.2012.11.011 〈http://www.sciencedirect.com/science/ article/pii/S0921510712005685\# fig0015 $\rangle$.

[23] M. Bivour, S. Schröer, M. Hermle, Numerical analysis of electrical TCO / a-Si: h(p) contact properties for silicon heterojunction solar cells, Energy Procedia 38 (2013) 658-669, https://doi.org/10.1016/j.egypro.2013.07.330〈http://www. sciencedirect.com/science/article/pii/S1876610213014161〉.

[24] R. Lachaume, W. Favre, P. Scheiblin, X. Garros, N. Nguyen, J. Coignus, D. Munoz, G. Reimbold, Influence of a-Si: H/ITO interface properties on performance of heterojunction solar cells, Energy Procedia 38 (2013) 770-776, https://doi.org/ 10.1016/J.EGYPRO.2013.07.345 〈http://www.sciencedirect.com/science/ article/pii/S1876610213014318?via\%3Dihub $\rangle$.

[25] A. Kanevce, W.K. Metzger, The role of amorphous silicon and tunneling in heterojunction with intrinsic thin layer (HIT) solar cells, J. Appl. Phys. 105 (9) (2009) 094507, https://doi.org/10.1063/1.3106642.

[26] N. Mingirulli, J. Haschke, R. Gogolin, R. Ferré, T.F. Schulze, J. Düsterhöft, N.P. Harder, L. Korte, R. Brendel, B. Rech, Efficient interdigitated back-contacted silicon heterojunction solar cells (2011)

[27] J.-C. Stang, T. Franssen, J. Haschke, M. Mews, A. Merkle, R. Peibst, B. Rech, L. Korte, Optimized metallization for interdigitated back contact silicon heterojunction solar cells, Sol. RRL (2017) 1700021, https://doi.org/10.1002/solr. 201700021 〈http://doi.wiley.com/10.1002/solr.201700021〉.

[28] J. Haschke, N. Mingirulli, R. Gogolin, R. Ferré, T.F. Schulze, J. Düsterhöft, N.P. Harder, L. Korte, Interdigitated back-contacted silicon heterojunction solar cells with improved fill factor and efficiency, IEEE J. Photovolt. 1 (2) (2011) 130-134.

[29] S. Harrison, O. Nos, G. D'Alonzo, C. Denis, A. Coll, D. Munoz, Back contact heterojunction solar cells patterned by laser ablation, Energy Procedia 92 (2016) 730-737, https://doi.org/10.1016/J.EGYPRO.2016.07.051 〈http://www. sciencedirect.com/science/article/pii/S1876610216304787?via\%3Dihub 〉.

[30] S. Ring, S. Kirner, C. Schultz, P. Sonntag, B. Stannowski, L. Korte, R. Schlatmann, Emitter patterning for back-contacted Si heterojunction solar cells using laser written mask layers for etching and self-aligned passivation (LEAP), IEEE J. Photovolt. 6 (4) (2016) 894-899, https://doi.org/10.1109/JPHOTOV.2016. $2566882\langle$ http://ieeexplore.ieee.org/document/7480759/ 〉.

[31] M. Xu, T. Bearda, M. Filipič, H.S. Radhakrishnan, I. Gordon, J. Szlufcik, J. Poortmans, Simple emitter patterning of silicon heterojunction interdigitated back-contact solar cells using damage-free laser ablation, Sol. Energy Mater. Sol Cells 186 (June) (2018) 78-83, https://doi.org/10.1016/j.solmat.2018.06.027 〈https://linkinghub.elsevier.com/retrieve/pii/S0927024818303155 〉.

[32] D. Spee, Preparations for Making Back Contacted Heterojunction Solar cells (Msc thesis), (2009)

[33] S.Y. Herasimenka, C.J. Tracy, W.J. Dauksher, C.B. Honsberg, S. Bowden, A simplified process flow for silicon heterojunction interdigitated back contact solar cells: Using shadow masks and tunnel junctions, 2014 IEEE Proceedings of the 40th Photovoltaic Specialist Conference, PVSC 2014 (i) (2014) 2486-2490. doi:10. 1109/PVSC. 2014.6925434.

[34] A. Tomasi, B. Paviet-Salomon, Q. Jeangros, J. Haschke, G. Christmann, L. Barraud, A. Descoeudres, J.P. Seif, S. Nicolay, M. Despeisse, S. De Wolf, C. Ballif, Simple processing of back-contacted silicon heterojunction solar cells using selective-area crystalline growth, Nat. Energy 2 (5) (2017) 17062, https://doi.org/10.1038/ nenergy. 2017.62

[35] M.A. Green, Y. Hishikawa, W. Warta, E.D. Dunlop, D.H. Levi, J. Hohl-Ebinger, A.W. Ho-Baillie, Solar cell efficiency tables (version 50), Prog. Photovolt.: Res. Appl. 25 (7) (2017) 668-676, https://doi.org/10.1002/pip.2909 〈http://doi. wiley.com/10.1002/pip.2909>.

[36] D.E. Carlson, C.R. Wronski, Amorphous silicon solar cell, Appl. Phys. Lett. 28 (11) (1976) 671-673, https://doi.org/10.1063/1.88617.

[37] A. Descoeudres, L. Barraud, S. De Wolf, B. Strahm, D. Lachenal, C. Guérin, Z.C. Holman, F. Zicarelli, B. Demaurex, J. Seif, J. Holovsky, C. Ballif, Improved amorphous/crystalline silicon interface passivation by hydrogen plasma treatment, Appl. Phys. Lett. 99 (12) (2011) 123506, https://doi.org/10.1063/1. 3641899 〈http://aip.scitation.org/doi/10.1063/1.3641899〉.

[38] M. Mews, T.F. Schulze, N. Mingirulli, L. Korte, Hydrogen plasma treatments for passivation of amorphous-crystalline silicon-heterojunctions on surfaces promoting epitaxy, Appl. Phys. Lett. 102 (12) (2013) 122106, https://doi.org/10 1063/1.4798292 〈http://scitation.aip.org/content/aip/journal/apl/102/12/10. $1063 / 1.4798292>$.

[39] T.F. Schulze, H.N. Beushausen, C. Leendertz, A. Dobrich, B. Rech, L. Korte, Interplay of amorphous silicon disorder and hydrogen content with interface defects in amorphous/crystalline silicon heterojunctions, Appl. Phys. Lett. 96 (25) (2010) 252102, https://doi.org/10.1063/1.3455900 〈http://aip.scitation.org/ doi/10.1063/1.3455900 >

[40] S. De Wolf, C. Ballif, M. Kondo, Kinetics of a-Si:H bulk defect and a-Si: H/c-si interface-state reduction, Phys. Rev. B - Condens. Matter Mater. Phys. 85 (11) (2012) 2-5, https://doi.org/10.1103/PhysRevB.85.113302.

[41] E.M. El Mhamdi, J. Holovsky, B. Demaurex, C. Ballif, S. De Wolf, Is light-induced degradation of a-Si: h/c-si interfaces reversible? Appl. Phys. Lett. 104 (25) (2014) 252108, https://doi.org/10.1063/1.4885501 〈http://aip.scitation.org/doi/10. $1063 / 1.4885501>$.

[42] E. Kobayashi, S. De Wolf, J. Levrat, G. Christmann, A. Descoeudres, S. Nicolay, M. Despeisse, Y. Watabe, C. Ballif, Light-induced performance increase of silicon heterojunction solar cells, Appl. Phys. Lett. 109 (15) (2016) 1-6, https://doi.org/ $10.1063 / 1.4964835$

[43] E. Kobayashi, S. De Wolf, J. Levrat, A. Descoeudres, M. Despeisse, F.J. Haug, C. Ballif, Increasing the efficiency of silicon heterojunction solar cells and modules by light soaking, Sol. Energy Mater. Sol. Cells 173 (March) (2017) 43-49, https:/ doi.org/10.1016/j.solmat.2017.06.023 〈https://doi.org/10.1016/j.solmat.2017. $06.023>$.

[44] J. Haschke, D. Amkreutz, B. Rech, Liquid phase crystallized silicon on glass: technology, material quality and back contacted heterojunction solar cells, Jpn. J. Appl. Phys. 55 (4S) (2016) 04EA04, https://doi.org/10.7567/JJAP.55.04EA04 〈http://stacks.iop.org/1347-4065/55/i $=4$ S/a $=04 \mathrm{EA04}$ ?key $=$ crossref. 5c5a068998381526df564591d18b3a7d >.

[45] S. Olibet, E. Vallat-Sauvain, L. Fesquet, C. Monachon, A. Hessler-Wyser, J. DamonLacoste, S. De Wolf, C. Ballif, Properties of interfaces in amorphous/crystalline silicon heterojunctions, Phys. Status Solidi (a) 207 (3) (2010) 651-656, https:// doi.org/10.1002/pssa.200982845 〈http://onlinelibrary.wiley.com/doi/10.1002/ pssa.200982845/abstract >.

[46] M. Galiazzo, A. Voltan, E. Bortoletto, M. Zamuner, M. Martire, O. Borsato, M. Bertazzo, D. Tonini, Fine line double printing and advanced process control for cell manufacturing, Energy Procedia 67 (2015) 116-125, https://doi.org/10. 1016/J.EGYPRO.2015.03.295 〈https://www.sciencedirect.com/science/article/ pii/S1876610215006013>.

[47] H. Hannebauer, T. Falcon, J. Cunnusamy, T. Dullweber, Single print metal stencils for high-efficiency PERC Solar Cells, Energy Procedia 98 (2016) 40-45, https:// doi.org/10.1016/J.EGYPRO.2016.10.079 〈http://www.sciencedirect.com/ science/article/pii/S1876610216310402 >.

[48] J. Geissbühler, S.D. Wolf, A. Faes, N. Badel, Q. Jeangros, A. Tomasi, L. Barraud, A. Descoeudres, M. Despeisse, C. Ballif, Silicon heterojunction solar cells with copper - plated grid electrodes: status and comparison with silver thick - film techniques, IEEE J. Photovolt. 4 (4) (2014) 1055-1062.

[49] T. Koida, H. Fujiwara, M. Kondo, Hydrogen-doped In 203 as High-mobility Transparent Conductive Oxide, Jpn. J. Appl. Phys. 46 (28) (2007) L685-L687, https://doi.org/10.1143/JJAP.46.L685 〈http://stacks.iop.org/1347-4065/46/ L685 >.

[50] L. Barraud, Z.C. Holman, N. Badel, P. Reiss, A. Descoeudres, C. Battaglia, S. De Wolf, C. Ballif, Hydrogen-doped indium oxide/indium tin oxide bilayers for highefficiency silicon heterojunction solar cells, Sol. Energy Mater. Sol. Cells 115 (2013) 151-156, https://doi.org/10.1016/j.solmat.2013.03.024 〈http://www. sciencedirect.com/science/article/pii/S0927024813001372 >.

[51] E. Kobayashi, Y. Watabe, T. Yamamoto, Y. Yamada, Cerium oxide and hydrogen co-doped indium oxide films for high-efficiency silicon heterojunction solar cells, Sol. Energy Mater. Sol. Cells 149 (2016) 75-80, https://doi.org/10.1016/j.solmat. 2016.01.005 〈http://www.sciencedirect.com/science/article/pii/ S092702481600009X >.

[52] T. Koida, Y. Ueno, H. Shibata, In2O3-Based transparent conducting oxide films with high electron mobility fabricated at low process temperatures, Phys. Status Solidi (A) Appl. Mater. Sci. 1700506 (2018) 1-14, https://doi.org/10.1002/pssa. 201700506.

[53] Z. Holman, A. Descoeudres, L. Barraud, F. Fernandez, J. Seif, S. De Wolf, C. Ballif, Current losses at the front of silicon heterojunction solar cells, IEEE J. Photovolt. 2 (1) (2012) 7-15, https://doi.org/10.1109/JPHOTOV.2011.2174967.

[54] A. Paduthol, M. Juhl, G. Nogay, P. Löper, T. Trupke, Measuring carrier injection from amorphous silicon into crystalline silicon using photoluminescence, Progress. Photovolt.: Res. Appl. (2018) 238-241, https://doi.org/10.1002/pip.3042 〈http://doi.wiley.com/10.1002/pip.3042 〉.

[55] M. Boccard, Z.C. Holman, Amorphous silicon carbide passivating layers for crystalline-silicon-based heterojunction solar cells, J. Appl. Phys. 118 (6) (2015) 065704, https://doi.org/10.1063/1.4928203 〈http://aip.scitation.org/doi/10. 1063/1.4928203 >.

[56] D. Zhang, D. Deligiannis, G. Papakonstantinou, R.A.C.M.M. van Swaaij, M. Zeman Optical Enhancement of silicon heterojunction solar cells with hydrogenated amorphous silicon carbide emitter, IEEE J. Photovolt. 4 (6) (2014) 1326-1330, https://doi.org/10.1109/JPHOTOV.2014.2344768 〈http://ieeexplore.iee.org/ document $/ 6881639 />$.

[57] L. Mazzarella, S. Kirner, B. Stannowski, L. Korte, B. Rech, R. Schlatmann, P-type microcrystalline silicon oxide emitter for silicon heterojunction solar cells allowing current densities above $40 \mathrm{~mA} / \mathrm{cm} 2$, Appl. Phys. Lett. 106 (2) (2015), https://doi.org/10.1063/1.4905906. 
[58] Y. Zhang, C. Yu, M. Yang, Y. He, L. Zhang, J. Zhang, X. Xu, Y. Zhang, X. Song, $\mathrm{H}$. Yan, Optimization of the window layer in large area silicon heterojunction solar cells, RSC Adv. 7 (15) (2017) 9258-9263, https://doi.org/10.1039/C6RA26342A $\langle$ http://xlink.rsc.org/?DOI = C6RA26342A 〉.

[59] A. Janotta, R. Janssen, M. Schmidt, T. Graf, M. Stutzmann, L. Görgens, A. Bergmaier, G. Dollinger, C. Hammerl, S. Schreiber, B. Stritzker, Doping and its efficiency in a-SiOx:H, Phys. Rev. B 69 (11) (2004) 115206, https://doi.org/10. 1103/PhysRevB.69.115206 〈https://link.aps.org/doi/10.1103/PhysRevB.69. $115206>$.

[60] P. Cuony, D.T.L. Alexander, I. Perez-Wurfl, M. Despeisse, G. Bugnon, M. Boccard, T. Söderström, A. Hessler-Wyser, C. Hébert, C. Ballif, Silicon filaments in silicon oxide for next-generation photovoltaics, Adv. Mater. 24 (9) (2012) 1182-1186, https://doi.org/10.1002/adma.201104578 〈http://onlinelibrary.wiley.com/doi/ 10.1002/adma.201104578/abstract >.

[61] A. Richter, V. Smirnov, A. Lambertz, K. Nomoto, K. Welter, K. Ding, Versatility of doped nanocrystalline silicon oxide for applications in silicon thin-film and heterojunction solar cells, Sol. Energy Mater. Sol. Cells 174 (2018) 196-201, https:// doi.org/10.1016/j.solmat.2017.08.035 〈http://dx.doi.org/10.1016/j.solmat. 2017.08.035 >.

[62] L. Mazzarella, A.B. Morales-Vilches, M. Hendrichs, S. Kirner, L. Korte, R. Schlatmann, B. Stannowski, Nanocrystalline n-type silicon oxide front contacts for silicon heterojunction solar cells: photocurrent enhancement on planar and textured substrates, IEEE J. Photovolt. 8 (1) (2017) 70-78, https://doi.org/10. 1109/JPHOTOV.2017.2770164.

[63] A.B. Morales-Vilches, L. Mazzarella, M. Hendrichs, L. Korte, R. Schlatmann, B. Stannowski, Nanocrystalline vs. amorphous n-type silicon front surface field layers in silicon heterojunction solar cells: Role of thickness and oxygen content, in: Proceedings of the 33rd European Photovoltaic Solar Energy Conference and Exhibition, Amsterdam, 2017, pp. 715 - 719. doi:10.4229/EUPVSEC20172017 2AV.3.3.

[64] J.P. Seif, A. Descoeudres, G. Nogay, S. Hanni, S.M. de Nicolas, N. Holm, J. Geissbuhler, A. Hessler-Wyser, M. Duchamp, R.E. Dunin-Borkowski, M. Ledinsky, S. De Wolf, C. Ballif, Strategies for doped nanocrystalline silicon integration in silicon heterojunction solar cells, IEEE J. Photovolt. 6 (5) (2016) 1132-1140, https://doi.org/10.1109/JPHOTOV.2016.2571619 〈http:// ieeexplore.ieee.org/document/7494651/ >.

65] P. Campbell, S. Wenham, M. Green, Light trapping and reflection control in solar cells using tilted crystallographic surface textures, Sol. Energy Mater. Sol. Cells 31 (2) (1993) 133-153, https://doi.org/10.1016/0927-0248(93)90046-6 〈http:// www.sciencedirect.com/science/article/pii/0927024893900466 >.

[66] Z.C. Holman, M. Filipič, A. Descoeudres, S.D. Wolf, F. Smole, M. Topič, C. Ballif, Infrared light management in high-efficiency silicon heterojunction and rearpassivated solar cells, J. Appl. Phys. 113 (1) (2013) 013107, https://doi.org/10. 1063/1.4772975 〈http://scitation.aip.org/content/aip/journal/jap/113/1/10. $1063 / 1.4772975\rangle$

[67] Z.C. Holman, A. Descoeudres, S.D. Wolf, C. Ballif, Record infrared internal quantum efficiency in silicon heterojunction solar cells with dielectric/metal rear reflectors, IEEE J. Photovolt. 3 (4) (2013) 1243-1249, https://doi.org/10.1109/ JPHOTOV.2013.2276484.

[68] F. Dross, E. Van Beaucarne, G. Kerschaver, Minimization of the Shadow-like Losses for Interdigitated Back-Junction Solar Cells, in: Proceedings of the 15th International Photovoltaic Science and Engineering Conference, Shanghai, 2005, pp. 971-972.

[69] M. Hermle, F. Granek, O. Schultz-Wittmann, S.W. Glunz, Shading Effects in BackJunction Back-Contacted Silicon Solar Cells, in: Proceedings of the 33rd IEEE Photovoltaic Specialist Conference, San Diego, CA, 2008, pp. 10-13. doi:10.1109/ PVSC. 2008.4922761.

[70] R. Street, D. Biegelsen, J. Stuke, Defects in bombarded amorphous silicon, Philos. Mag. B 40 (6) (1979) 451-464, https://doi.org/10.1080/01418637908226769.

[71] B. Demaurex, S.D. Wolf, A. Descoeudres, Z.C. Holman, C. Ballif, Damage at hydrogenated amorphous/crystalline silicon interfaces by indium tin oxide overlayer sputtering, Appl. Phys. Lett. 101 (17) (2012) 171604, https://doi.org/10.1063/1. 4764529 〈http://scitation.aip.org/content/aip/journal/apl/101/17/10.1063/1. $4764529>$.

72] B.M. Meiners, D. Borchert, S. Hohage, S. Holinksi, P. Schäfer, Degradation of hydrogenated amorphous silicon passivation films caused by sputtering deposition, Phys. Status Solidi (A) Appl. Mater. Sci. 212 (8) (2015) 1817-1822, https:// doi.org/10.1002/pssa.201431923.

[73] L. Tutsch, M. Bivour, W. Wolke, M. Hermle, J. Rentsch, Influence of the transparent electrode sputtering process on the interface passivation quality of silicon heterojunction solar cells, in: Proceedings of the 33rd European PV Solar Energy Conference and Exhibition, no. September, Amsterdam, 2017.

[74] B.M. Meiners, S. Holinksi, P. Schäfer, S. Hohage, D. Borchert, Sputter damage to amorphous silicon layers for heterojunction solar cells, in: Proceedings of the 31st European Photovoltaic Solar Energy Conference and Exhibition, 2015, pp. 1284-1286. doi:10.4229/EUPVSEC20152015-3DV.2.2.

[75] B. Demaurex, J.P. Seif, S. Smit, B. Macco, W.M.M.E. Kessels, J. Geissbühler, S. De Wolf, C. Ballif, Atomic-layer-deposited transparent electrodes for silicon heterojunction solar cells, IEEE J. Photovolt. 4 (6) (2014) 1387-1396, https://doi.org/ 10.1109/JPHOTOV.2014.2344771.

[76] F. Haase, S. Schafer, C. Klamt, F. Kiefer, J. Krugener, R. Brendel, R. Peibst, Perimeter recombination in 25\%-efficient IBC solar cells with passivating POLO contacts for both polarities, IEEE J. Photovolt. 8 (1) (2017) 23-29, https://doi. org/10.1109/JPHOTOV.2017.2762592 〈http://ieeexplore.ieee.org/document/ $8094348 />$.

[77] P.P. Altermatt, G. Heiser, M.A. Green, Numerical quantification and minimization of perimeter losses in high-efficiency silicon solar cells, Prog. Photovolt.: Res. Appl. 4 (5) (1996) 355-367, https://doi.org/10.1002/(SICI)1099-159X(199609/ 10) 4:5<355::AID-PIP145> 3.0.CO;2-X.

[78] M.A. Green, K. Emery, Y. Hishikawa, W. Warta, E.D. Dunlop, D.H. Levi, A.W.Y. Ho-Baillie, Solar cell efficiency tables (version 49), Progress. Photovolt.: Res. Appl. 25 (1) (2017) 3-13, https://doi.org/10.1002/pip.2855 (URL 〈http:// doi.wiley.com/10.1002/pip.2855 >)

[79] U. Würfel, A. Cuevas, P. Würfel, U. Wurfel, A. Cuevas, P. Wurfel, Charge carrier separation in solar cells, IEEE J. Photovolt. 5 (1) (2015) 461-469, https://doi.org/ 10.1109/JPHOTOV.2014.2363550.

[80] R. Rößler, C. Leendertz, L. Korte, N. Mingirulli, B. Rech, Impact of the transparen conductive oxide work function on injection-dependent a-Si:H/c-Si band bending and solar cell parameters, J. Appl. Phys. 113 (14) (2013), https://doi.org/10. 1063/1.4799042.

[81] S. Kirner, M. Hartig, L. Mazzarella, L. Korte, T. Frijnts, H. Scherg-Kurmes, S. Ring, B. Stannowski, B. Rech, R. Schlatmann, The influence of ITO dopant density on J-V characteristics of silicon heterojunction solar cells: experiments and simulations, Energy Procedia 77 (2015) 725-732, https://doi.org/10.1016/j.egypro.2015.07. 103 〈http://www.sciencedirect.com/science/article/pii/S1876610215008711 〉.

[82] M. Bivour, M. Reusch, S. Schroer, F. Feldmann, J. Temmler, H. Steinkemper, M. Hermle, Doped layer optimization for silicon heterojunctions by injection-leveldependent open-circuit voltage measurements, IEEE J. Photovolt. 4 (2) (2014) 566-574, https://doi.org/10.1109/JPHOTOV.2013.2294757.

[83] M. Mikolášek, J. Racko, L. Harmatha, Analysis of low temperature output parameters for investigation of silicon heterojunction solar cells, Appl. Surf. Sci. 395 (2017) 166-171, https://doi.org/10.1016/j.apsusc.2016.04.023.

[84] J. Geissbühler, J.J. Werner, S.M. de Nicolas, L. Barraud, A.A. Hessler-Wyser, M. Despeisse, S. Nicolay, A. Tomasi, B. Niesen, S.D. Wolf, C. Ballif, J. Geissbühler, J.J. Werner, S. Martin De Nicolas, L. Barraud, A.A. Hessler-Wyser, M. Despeisse, S. Nicolay, A. Tomasi, B. Niesen, S. De Wolf, C. Ballif, 22.5\% Efficient silicon heterojunction solar cell with molybdenum oxide hole collector, Appl. Phys. Lett. 107 (8) (2015) 081601, https://doi.org/10.1063/1.4928747 〈http://scitation.aip. org/content/aip/journal/apl/107/8/10.1063/1.4928747http://scitation.aip.org/ content/aip/journal/apl/107/8/10.1063/1.4928747 >.

[85] M. Bivour, J. Temmler, H. Steinkemper, M. Hermle, Molybdenum and tungsten oxide: high work function wide band gap contact materials for hole selective contacts of silicon solar cells, Sol. Energy Mater. Sol. Cells 142 (2015) 34-41, https://doi.org/10.1016/j.solmat.2015.05.031.

[86] M. Mews, A. Lemaire, L. Korte, Sputtered Tungsten Oxide as Hole Contact for Silicon Heterojunction Solar Cells, IEEE J. Photovolt. 7 (5) (2017) 1209-1215, https://doi.org/10.1109/JPHOTOV.2017.2714193.

[87] J. Bullock, Y. Wan, Z. Xu, S. Essig, M. Hettick, H. Wang, W. Ji, M. Boccard, A Cuevas, C. Ballif, A. Javey, Stable dopant-free asymmetric heterocontact silicon solar cells with efficiencies above $20 \%$ (2018) 3-8, doi: 〈http://dx.doi.org/10. 1021/acsenergylett.7b01279〉. URL 〈http://pubs.acs.org.recursos.biblioteca.upc. edu/doi/pdf/10.1021/acsenergylett.7b01279〉.

[88] X. Yang, K. Weber, Z. Hameiri, S.De Wolf, Industrially feasible, dopant-free, carrier-selective contacts for high-efficiency silicon solar cells, Prog. Photovolt.: Res. Appl. 25 (11) (2017) 896-904, https://doi.org/10.1002/pip.2901 〈http://doi. wiley.com/10.1002/pip.2901 >.

[89] Z.C. Holman, M. Filipič, B. Lipovšek, S. De Wolf, F. Smole, M. Topič, C. Ballif, Parasitic absorption in the rear reflector of a silicon solar cell: simulation and measurement of the sub-bandgap reflectance for common dielectric/metal reflectors, Sol. Energy Mater. Sol. Cells 120, Part (2014) 426-430, https://doi.org/ 10.1016/j.solmat.2013.06.024 〈http://www.sciencedirect.com/science/article/ pii/S0927024813003097>.

[90] M. Boccard, L. Ding, P. Koswatta, M. Bertoni, Z. Holman, Evaluation of metal oxides prepared by reactive sputtering as carrier-selective contacts for crystalline silicon solar cells, in: Proceedings of the IEEE 42nd Photovoltaic Specialist Conference (PVSC) (2015) 1-3 doi:10.1109/PVSC.2015.7356167. URL 〈http:// ieexplore.ieee.org/lpdocs/epic03/wrapper.htm?Arnumber $=7356167\rangle$.

[91] R.P. Causin, Hole-selective contacts by RF magnetron sputtering for silicon het erojunction solar cell structures, Bachelor's thesis, Universitat Politecnica de Catalunya, 2017, https://upcommons.upc.edu/bitstream/handle/2117/106470/ TFG.pdf? sequence $=1$ \&isAllowed $=y$.

[92] W. Wu, W. Lin, J. Bao, Z. Liu, B. Liu, K. Qiu, Y. Chen, H. Shen, Dopant-free multilayer back contact silicon solar cells employing V2Ox /metal/V2Ox as an emitter, RSC Adv. 7 (38) (2017) 23851-23858, https://doi.org/10.1039/ C7RA03368K 〈http://xlink.rsc.org/?DOI = C7RA03368K 〉.

[93] W. Wu, W. Lin, S. Zhong, B. Paviet-Salomon, Q. Jeangros, Z. Liang, H. Shen, M. Boccard, C. Ballif, Dopant-free back contact silicon solar cells employing low interfacial recombination and work-function mismatch of metal-metal contact, manuscript in preparation.

[94] S. Avasthi, S. Lee, Y.L. Loo, J.C. Sturm, Role of majority and minority carrier barriers silicon/organic hybrid heterojunction solar cells, Adv. Mater. 23 (48) (2011) 5762-5766, https://doi.org/10.1002/adma.201102712.

[95] D. Zielke, C. Niehaves, W. Lövenich, A. Elschner, M. Hörteis, J. Schmidt, Organicsilicon Solar Cells Exceeding 20\% Efficiency, Energy Procedia 77 (2015) 331-339, https://doi.org/10.1016/j.egypro.2015.07.047 〈http://dx.doi.org/10.1016/j. egypro.2015.07.047>

[96] C. Reichel, R. Müller, F. Feldmann, A. Richter, M. Hermle, S.W. Glunz, Influence of the transition region between p- and n-type polycrystalline silicon passivating contacts on the performance of interdigitated back contact silicon solar cells, J. Appl. Phys. 122 (18) (2017) 184502, https://doi.org/10.1063/1.5004331 〈https://doi.org/10.1063/1.5010937\%0A 〉〈http://aip.scitation.org/toc/jap/ 123/2 〉〈http://aip.scitation.org/doi/10.1063/1.5004331 〉. 
[97] C. Messmer, M. Bivour, J. Schön, S.W. Glunz, M. Hermle, Numerical Simulation of Silicon Heterojunction Solar Cells Featuring Metal Oxides as Carrier-Selective Contacts, IEEE J. Photovolt. 8 (2) (2018) 456-464, https://doi.org/10.1109/ JPHOTOV.2018.2793762 〈http://ieeexplore.ieee.org/document/8291499/〉.

[98] J. Haschke, J.P. Seif, Y. Riesen, A. Tomasi, J. Cattin, L. Tous, P. Choulat, M. Aleman, E. Cornagliotti, A. Uruena, R. Russell, F. Duerinckx, J. Champliaud, J. Levrat, A.A. Abdallah, B. Aïssa, N. Tabet, N. Wyrsch, M. Despeisse, J. Szlufcik, S. De Wolf, C. Ballif, The impact of silicon solar cell architecture and cell interconnection on energy yield in hot \& sunny climates, Energy Environ. Sci. 10 (5) (2017) 1196-1206, https://doi.org/10.1039/C7EE00286F 〈http://xlink.rsc.org/? $\mathrm{DOI}=\mathrm{C} 7 \mathrm{EE} 00286 \mathrm{~F}>$.

[99] M.A. Green, Solar cell fill factors: general graph and empirical expressions, SolidState Electron. 24 (8) (1981) 788-789, https://doi.org/10.1016/0038-1101(81) 90062-9 〈http://www.sciencedirect.com/science/article/pii/ $0038110181900629\rangle$.

[100] M. Taguchi, E. Maruyama, M. Tanaka, Temperature dependence of amorphous crystalline silicon heterojunction solar cells, Jpn. J. Appl. Phys. 47 (2R) (2008) $814\langle$ http://iopscience.iop.org/1347-4065/47/2R/814〉.

[101] A.V. Sachenko, Y.V. Kryuchenko, V.P. Kostylyov, A.V. Bobyl, E.I. Terukov, S.N. Abolmasov, A.S. Abramov, D.A. Andronikov, M.Z. Shvarts, I.O. Sokolovskyi, M. Evstigneev, Temperature dependence of photoconversion efficiency in silicon heterojunction solar cells: theory vs experiment, J. Appl. Phys. 119 (22) (2016) 225702, https://doi.org/10.1063/1.4953384 〈http://scitation.aip.org/content/ aip/journal/jap/119/22/10.1063/1.4953384 >.

[102] J. Haschke, R. Monnard, L. Antognini, J. Cattin, A.A. Abdallah, B. Aïssa, M.M Kivambe, N. Tabet, M. Boccard, C. Ballif, Nanocrystalline Silicon Oxide Stacks for Silicon Heterojunction Solar Cells for Hot Climates, in: presented at SiliconPV 2018, AIP Publishing, Lausanne, 2018.

[103] K.R. McIntosh, R.M. Swanson, J.E. Cotter, A simple ray tracer to compute the optical concentration of photovoltaic module, Progress in Photovoltaics: Research and Applications doi:10.1002/pip.647.

[104] O. Dupré, J. Levrat, J. Champliaud, M. Despeisse, M. Boccard, C. Ballif, Reassessment of cell to module gains and losses: Accounting for the current boost specific to cells located on the edges, in: Proceedings of the SiliconPV conference, 2018.

[105] International Technology Roadmap for Photovoltaic (ITRPV), Tech. rep. (2018). URL 〈http://www.itrpv.org〉.

[106] H. Hanifi, C. Pfau, D. Dassler, J. Schneider, S. Schindler, M. Turek, J. Bagdahn, Investigation of cell-to-module (CTM) ratios of PV modules by analysis of loss and gain mechanisms, Photovolt. Int. 32 (2016) 89-99 〈https://www.researchgate. net/publication/303783079_Investigation_of_cell-to-module_CTM_ratios_of_PV modules by analysis of loss and gain mechanisms $>$.

[107] M. Mittag, T. Zech, M. Wiese, D. Bläsi, M. Ebert, H. Wirth, Cell-to-Module (CTM) Analysis for Photovoltaic Modules with Shingled Solar Cells, in: Proceedings of the 44th IEEE Photovoltaic Specialists Conference, Washington, DC, USA, 2017.

[108] C. Ballif, J. Dicker, D. Borchert, T. Hofmann, Solar glass with industrial porous SiO2 antireflection coating: measurements of photovoltaic module properties improvement and modelling of yearly energy yield gain, Sol. Energy Mater. Sol. Cells 82 (3) (2004) 331-344, https://doi.org/10.1016/j.solmat.2003.12.004 〈http://linkinghub.elsevier.com/retrieve/pii/S0927024804000376 〉.

[109] L.L. Bucciarelli, Power loss in photovoltaic arrays due to mismatch in cell characteristics, Sol. Energy 23 (4) (1979) 277-288, https://doi.org/10.1016/0038092X(79)90121-X 〈http://linkinghub.elsevier.com/retrieve/pii/ $0038092 X 7990121 X\rangle$

[110] R. Evans, K.H. Kim, X. Wang, A. Sugianto, X. Chen, R. Chen, M.A. Green, Simplified technique for calculating mismatch loss in mass production, Sol. Energy Mater. Sol. Cells 134 (2015) 236-243, https://doi.org/10.1016/j.solmat.2014.11. $036\langle$ http://dx.doi.org/10.1016/j.solmat.2014.11.036〉.

[111] M. Tanaka, S. Okamoto, S. Tsuge, S. Kiyama, Development of hit solar cells with more than $21 \%$ conversion efficiency and commercialization of highest performance hit modules, World 1 (2003) 955-958.

[112] Y. Shigesato, S. Takaki, T. Haranoh, Electrical and structural properties of low resistivity tin-doped indium oxide films, J. Appl. Phys. 71 (7) (1992) 3356-3364, https://doi.org/10.1063/1.350931.

[113] Y. Shigesato, Y. Hayashi, T. Haranoh, Doping mechanisms of tin-doped indium oxide films, Appl. Phys. Lett. 61 (1) (1992) 73-75, https://doi.org/10.1063/1 107673.

[114] J. Geissbühler, A. Faes, A. Lachowicz, C. Ballif, M. Despeisse, Metallization techniques and interconnection schemes for high-efficiency silicon heterojunction photovoltaics, Photvoltaics Int. 37 (2017) 61-69.

[115] O. Dupré, R. Vaillon, M. Green, Thermal Behavior of Photovoltaic Devices: Physics and Engineering, Springer International Publishing, 2017, https://doi.org/10 1007/978-3-319-49457-9.

[116] Panasonic Corp., N330/N325 module specsheet (2018). URL 〈ftp://ftp.panasonic.

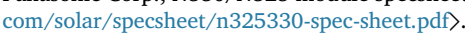

[117] A. Bubenzer, J. Schmitt, Plasma processes under vacuum conditions, Vacuum 41 (7-9) (1990) 1957-1961, https://doi.org/10.1016/0042-207X(90)94144-F 〈http://linkinghub.elsevier.com/retrieve/pii/0042207X9094144F 〉.

[118] H. Schmidt, L. Sansonnens, A.A. Howling, C. Hollenstein, M. Elyaakoubi, J.P. Schmitt, Improving plasma uniformity using lens-shaped electrodes in a large area very high frequency reactor, J. Appl. Phys. 95 (9) (2004) 4559-4564, https:// doi.org/10.1063/1.1690096.

[119] A. Shah, J. Meier, A. Buechel, U. Kroll, J. Steinhauser, F. Meillaud, H. Schade, D. Dominé, Towards very low-cost mass production of thin-film silicon photovoltaic (PV) solar modules on glass, Thin Solid Films 502 (1-2) (2006) 292-299, https://doi.org/10.1016/j.tsf.2005.07.299.

[120] INDEOtec PECVD technology, (Accessed 24 May 2018) (2018). URL 〈https:// www.indeotec.com/indeotec-our-technology-pecvd-classic.html $\rangle$.

[121] Applied Materials, AKT PECVD - LTPS (2018). URL 〈http://www appliedmaterials.com/files/pdf_documents/100400_AKT_Products_LTPS released3.pdf>.

[122] Y.C. Wang, Mono Wafer requirements for advanced High Efficiency Silicon Solar cells, in: nPV workshop, Lausanne, 2018.

[123] P. Papet, L. Andreetta, D. Lachenal, G. Wahli, J. Meixenberger, B. Legradic, W. Frammelsberger, D. Bätzner, B. Strahm, Y. Yao, T. Söderström, New cell metallization patterns for heterojunction solar cells interconnected by the smart wire connection technology, Energy Procedia 67 (2015) 203-209, https://doi.org/10. 1016/j.egypro.2015.03.039 〈http://dx.doi.org/10.1016/j.egypro.2015.03.039 〉.

[124] M. Despeisse, C. Ballif, A. Faes, A. Lachowicz, Metallization and interconnection for silicon heterojunction solar cells and modules, Photovoltaics International 30 (February).

[125] A. Descoeudres, C. Allebé, N. Badel, L. Barraud, J. Champliaud, G. Christmann, F. Debrot, A. Faes, J. Geissbühler, J. Horzel, A. Lachowicz, J. Levrat, S. Martin de Nicolas, S. Nicolay, B. Paviet-Salomon, L.-L. Senaud, C. Ballif, M. Despeisse, Lowtemperature processes for passivation and metallization of high-efficiency crystalline silicon solar cells, Sol. Energy (November 2017) (2018) 0-1, https://doi org/10.1016/j.solener.2018.01.074 〈https://ac.els-cdn.com/ S0038092X18300951/1-s2.0-S0038092X18300951-main.pdf? tid = b09a3d180b33-11e8-a601-00000aab0f01\&acdnat $=1517917907$. adf8345584f51fb4bf45399c755a4cdd 〉〈http://linkinghub.elsevier.com/retrieve/ pii/S0038092X18300951>.

[126] C. Ballif, L. Barraud, A. Descoeudres, Z.C. Holman, S. Morel, S. De Wolf, A-Si:H/cSi heterojunctions: a future mainstream technology for high-efficiency crystalline silicon solar cells?, in: 2012 Proceedings of the 38th IEEE Photovoltaic Specialists Conference, IEEE, 2012, pp. 001705-001709. doi:10.1109/PVSC.2012.6317924.

[127] B. Legradic, B. Strahm, D. Lachenal, D. Batzner, W. Frammelsberger, J. Meixenberger, P. Papet, G. Wahli, J. Zhao, D. Decker, E. Vetter, High efficiency Siheterojunction technology - It's ready for mass production, in: 2015 IEEE Proceedings of the 42nd Photovoltaic Specialist Conference, PVSC 2015, 2015, pp. 6-8. doi:10.1109/PVSC.2015.7355747.

[128] O. Shojaei, A. Descoeudres, U. Kroll, L. Barraud, F. Jeanneret, A. Limouzin, M. Despeisse, C. Ballif, New concept of PECVD reactor for efficient production of silicon heterojunction solar cells, in: 2015 IEEE Proceedings of the 42nd Photovoltaic Specialist Conference (PVSC), 2015, pp. 1-4. doi:10.1109/PVSC 2015.7356315. URL 〈http://ieeexplore.ieee.org/lpdocs/epic03/wrapper.htm? Arnumber $=7356315\rangle$.

[129] Meyer Burger, Meyer Burger Technology Day 2017 premiers Heterojunction / SmartWire module with 335 Watt efficiency as confirmed by TÜV Rheinland strong momentum in incoming orders confirmed (2017). URL 〈https://www. meyerburger.com/it/en/meyer-burger/media/news-detail/article/meyer-burger technology-day-2017-premiers-heterojunction-smartwire-module-with-335-wattefficiency $/>$.

[130] H.W. Deckman, C.R. Wronski, H. Witzke, E. Yablonovitch, Optically enhanced amorphous silicon solar cells, Appl. Phys. Lett. 42 (11) (1983) 968-970, https:// doi.org/10.1063/1.93817.

[131] M. Boccard, C. Battaglia, F.-J. Haug, M. Despeisse, C. Ballif, Light trapping in sola cells: analytical modeling, Appl. Phys. Lett. 101 (15) (2012) 151105, https://doi. org/10.1063/1.4758295〈http://aip.scitation.org/doi/10.1063/1.4758295〉.

[132] M.A. Green, Self-consistent optical parameters of intrinsic silicon at $300>\mathrm{K}$ including temperature coefficients, Sol. Energy Mater. Sol. Cells 92 (11) (2008) 1305-1310, https://doi.org/10.1016/j.solmat.2008.06.009 〈http://www. sciencedirect.com/science/article/pii/S0927024808002158 >.

[133] W. Shockley, W.T. Read, Statistics of the Recombinations of Holes and Electrons, Phys. Rev. 87 (5) (1952) 835-842, https://doi.org/10.1103/PhysRev.87.835 〈http://link.aps.org/doi/10.1103/PhysRev.87.835 〉.

[134] A. Richter, S.W. Glunz, F. Werner, J. Schmidt, A. Cuevas, Improved quantitative description of Auger recombination in crystalline silicon, Phys. Rev. B 86 (16) (2012) 165202-1-165202-14, https://doi.org/10.1103/PhysRevB.86.165202 〈http://link.aps.org/doi/10.1103/PhysRevB.86.165202 〉.

[135] K. Misiakos, D. Tsamakis, Accurate measurements of the silicon intrinsic carrie density from 78 to 340 K, J. Appl. Phys. 74 (5) (1993) 3293-3297, https://doi. org/10.1063/1.354551 〈http://scitation.aip.org/content/aip/journal/jap/74/5/ $10.1063 / 1.354551>$

[136] S. Olibet, E. Vallat-Sauvain, C. Ballif, Model for a-Si: H/c-si interface recombination based on the amphoteric nature of silicon dangling bonds, Phys. Rev. B 76 (3) (2007) 035326, https://doi.org/10.1103/PhysRevB.76.035326 〈http://link.aps. org/doi/10.1103/PhysRevB.76.035326 >.

[137] A.B. Sproul, Dimensionless solution of the equation describing the effect of surface recombination on carrier decay in semiconductors, J. Appl. Phys. 76 (5) (1994) 2851-2854, https://doi.org/10.1063/1.357521 〈http://aip.scitation.org/doi/10. $1063 / 1.357521>$ 